\title{
THE VOTE IS CAST: \\ THE EFFECT OF CORPORATE GOVERNANCE ON SHAREHOLDER VALUE
}

\author{
Vicente Cuñat \\ Mireia Gine \\ Maria Guadalupe \\ Working Paper 16574 \\ http://www.nber.org/papers/w16574
}

\author{
NATIONAL BUREAU OF ECONOMIC RESEARCH \\ 1050 Massachusetts Avenue \\ Cambridge, MA 02138 \\ December 2010
}

We are grateful to Ashwini Agrawal, Ann Bartel, Ken Chay, Jeff Coles, Ray Fisman, Laurie Hodrick, Marco Manacorda, Jan Eeckhout, Denis Gromb, Zacharias Sautner, David Yermack and seminar participants at Brown University, Columbia Business School, the University of Edinburgh, Goethe University, LeBow College of Business Conference on Corporate Governance, the London School of Economics, University of Michigan, the New York University Paduano Seminar, and the University of Oregon for their helpful comments and suggestions. Raymond Lim provided excellent research assistance. The views expressed herein are those of the authors and do not necessarily reflect the views of the National Bureau of Economic Research.

NBER working papers are circulated for discussion and comment purposes. They have not been peerreviewed or been subject to the review by the NBER Board of Directors that accompanies official NBER publications.

(C) 2010 by Vicente Cuñat, Mireia Gine, and Maria Guadalupe. All rights reserved. Short sections of text, not to exceed two paragraphs, may be quoted without explicit permission provided that full credit, including $\odot$ notice, is given to the source. 
The Vote is Cast: The Effect of Corporate Governance on Shareholder Value

Vicente Cuñat, Mireia Gine, and Maria Guadalupe

NBER Working Paper No. 16574

December 2010

JEL No. D21,G14,G34

\section{ABSTRACT}

This paper estimates the effect of corporate governance provisions on shareholder value and long-term outcomes in S\&P1500 firms. We apply a regression discontinuity design to shareholder votes on governance proposals in annual meetings. A close-call vote around the majority threshold is akin to a random outcome, allowing us to deal with prior expectations and the endogeneity of internal governance rules. Passing a corporate governance provision generates a $1.3 \%$ abnormal return on the day of the vote with an implied market value per provision of $2.8 \%$. We also find evidence of changes in investment behavior and long-term performance improvements.

Vicente Cuñat

The London School of Economics

Houghton Street WC2A 2AE

London - United Kingdom

v.cunat@1se.ac.uk

Mireia Gine

Wharton Research Data Services

The Wharton School at the

University of Pennsylvania

3451 Walnut Street

Philadelphia, PA 19104

gine@wharton.upenn.edu
Maria Guadalupe

Graduate School of Business

Columbia University

3022 Broadway, Uris Hall 624

New York, NY 10027

and NBER

mg2341@columbia.edu 


\section{Introduction}

The agency problem - the conflict created by the misalignment of incentives between owners and managers - is at the heart of our understanding of how firms work (Berle and Means, 1932; Jensen and Meckling, 1976); and the corporate governance structure of the firm should be designed to minimize the costs created by that conflict. Yet, a critical element of corporate governance in modern corporations are provisions that protect managers from the external discipline of takeovers (such as poison pills, staggered boards or golden parachutes) and statutes that insulate them from the monitoring and control of shareholders (Gompers, Ishii and Metrick, 2003; Bebchuck, Cohen and Ferrell, 2004). It may be appropriate to protect managers in this way if excessive shareholder oversight is disruptive or encourages them to focus on short-term gains at the expense of long-term performance (Comment and Schwert, 1995; Stein, 1988). Some have argued, however, that boards of directors are not sufficiently independent from management and that shareholder activism may have limited ability to bring about effective control. As a result, current corporate governance arrangements may not result from an optimal decision by shareholders; but rather they may reflect imperfections in the firm's political process and the excessive power of constituencies with other goals (Bertrand and Mullainathan, 2001 and 2003; Perez-Gonzalez, 2006; Bennedsen et al., 2007).

Establishing empirically how increasing shareholder rights affects shareholder value, and what type of shareholder rights have bigger effects, is essential for our understanding of the internal governance of firms. It also has clear implications for the debate on shareholder oversight and regulatory reform of corporate governance. Prior research has shown that legislative changes that affect external governance measures, such as state-level anti-takeover legislation, increase managerial slack and reduce performance (Bertrand and Mullainathan, 2003; Garvey and Hanka, 1999; Giroud and Mueller, forthcoming). Internal governance arrangements, the ones developed by the firm itself, have been the subject of much research, but the evidence provided in these papers is mixed and, most importantly, based on correlations rather than causal estimates. ${ }^{1}$ This paper provides a causal estimate of the effect of changes in the firm's internal corporate governance structure resulting from shareholder governance proposals at annual meetings -, on shareholder value and managers' behavior.

In practice, it is generally difficult to find a setting where a firm's governance structure changes

\footnotetext{
${ }^{1}$ See the surveys by Shleifer and Vishny (1997), and Becht, Bolton and Röell (2005). In their influential paper, Gompers, Ishii and Metrick (2003) found that, in the 1990s, a trading strategy that bought firms with better governance and sold those with worse governance achieved an $8.5 \%$ annual excess return. However, others have questioned whether there could be any systematic long-run excess returns since these should be incorporated immediately in stock prices (Core, Guay and Rusticus, 2006).
} 
exogenously such that we can estimate a causal effect. We argue that a regression discontinuity design on the outcomes of shareholder proposals in annual meetings provides us with this ideal quasi-experimental setting (Cellini, Ferreira and Rothstein, 2010). It also allows us to overcome two important limitations of any analysis based on a regression of stock-market returns on the presence of governance provisions. First, the choice of governance structure and the type of provisions adopted by firms is arguably endogenous and correlated with other firm characteristics; thus, comparing the returns of firms with different governance structures is likely to capture the effect of those unobserved characteristics, rather than the effect of governance. Second, if investors know about the superior performance of better-governed firms, their knowledge should be incorporated into prices, and we should not observe any systematic differences in abnormal returns (as emphasized by Core, et al., 2006). To overcome these limitations, we need a setting in which governance rules are exogenously or "randomly" adopted and, at the same time, one in which their adoption is not foreseen by the market and incorporated into returns.

In their annual meetings, shareholders propose and vote on a large number of governancerelated provisions. ${ }^{2}$ Our approach is to use a regression discontinuity design that compares the reaction of the stock market to shareholder-sponsored governance proposals that pass by a small margin to the reaction to those that fail by a small margin. We show that, even though these proposals are not binding, passing a proposal by a small margin discretely increases its probability of implementation. For these close-call proposals, passing is akin to an independent random event (it is "locally" exogenous) and, therefore, uncorrelated with firm characteristics. This approach is immune, by construction, to any observed or unobserved confounding factors as long as their effect is continuous around the threshold. We show that indeed, for votes around the majority threshold, passing is uncorrelated with observed firm and meeting characteristics, such that by focusing on these proposals we can estimate a causal effect. In addition, it is precisely for these close-call proposals that the vote contains substantial information -switching from an unpredictable outcome to either pass or fail- that is not already fully incorporated in prices. We present an analytical framework that shows how stock prices should react for each observed vote outcome; this allows us to recover the value of passing a provision from the outcome of votes around the majority threshold. We also discuss how the observed reaction varies with the probability of implementing a proposal and other information that may be contained in the vote outcome. This is, in a nutshell, the regression discontinuity design that provides us with causal estimates of the effect of shareholder-sponsored

\footnotetext{
${ }^{2}$ These include provisions that lower takeover barriers, regulate the independence of the board from management, define the voting rules in annual meetings, and decide on executive and board compensation.
} 
proposals.

Our dataset includes all shareholder-sponsored governance proposals voted on in U.S. firms in the S\&P 1500 (plus another 500 widely held firms) between 1997 and 2007. We restrict ourselves to these proposals given that (unlike management-sponsored ones) shareholder proposals cannot be removed strategically by the management of the firm, and their vote distribution is not affected by selective withdrawal around the discontinuity (see Listokin, 2008 and section 4). ${ }^{3}$ Given the structure of our data, we adopt the empirical dynamic regression discontinuity model proposed by Cellini, Ferreira and Rothstein (2010), and we allow the result of the vote in any given annual meeting to affect future outcomes and the votes in future meetings. We also adapt this methodology to deal with multiple votes in one meeting.

The results show that, on the day of the vote, a shareholder governance proposal that passes yields an abnormal return of $1.3 \%$ relative to one that fails; there are no significant additional returns on subsequent days. This price reaction is more pronounced for the set of anti-takeover provisions included in the G-index developed by Gompers et al. (2003), suggesting that these are important for governance (since Jensen, 1986, it has been argued that takeover threats are an important form of managerial discipline). ${ }^{4}$ In particular, the effect is largely driven by proposals to eliminate classified boards and poison pills, which represent $68 \%$ of G-Index proposals that fall around the majority threshold. We also find that other proposals, such as those increasing board independence, have a positive, but weaker, effect on returns. Finally, we find that the effect is stronger among firms with concentrated ownership, for those with a large number of anti-takeover provisions in place, and for those with high R\&D expenditures.

Since the outcome of these votes is not binding, the price reaction is likely to underestimate the full value of implementing these proposals. In addition, passing a proposal may affect the probability that other provisions are submitted and passed in the future. To estimate the value of implementing a proposal, we need to take this information into account. We estimate that passing a proposal around the discontinuity leads to a discrete $31 \%$ increase in the probability of implementation (we measure implementation as the change in the number of anti-takeover provisions the firm has in place) and to an increase in the probability of proposing and passing proposals in future meetings. Using these probabilities, we calculate that, for the S\&P 1500 firms in our sample, adopting a

\footnotetext{
${ }^{3}$ This yields almost 4,000 proposals. We restrict ourselves to these shareholder-sponsored proposals given that (unlike management-sponsored ones) shareholder proposals cannot be removed by the management of the firm, and their vote distribution is not affected by strategic withdrawal around the discontinuity (see Listokin, 2008 and section 4).

${ }^{4}$ The G-index is the number of anti-takeover provisions the firm has in place.
} 
governance proposal increases shareholder value by $2.8 \%$. This is a non-negligible effect.

The estimated stock-price reaction may reflect the expectation of changes in performance from governance improvements, as well as the implied reduction in agency costs, but it may also reflect a pure takeover premium (if a takeover is more likely under the new governance arrangement). To explore these two possible explanations, we examine the real effects beyond the stock-price reaction on the day of the vote. The regression discontinuity design allows us to study the effect of the new governance arrangements on variables such as acquisitions and capital expenditures, which have been used as proxies for empire building and potentially inefficient behavior (e.g., Gompers et al., 2003; Bertrand and Mullainathan 2003). We find that acquisitions and capital expenditures fall as a result of passing corporate governance proposals. We also find evidence that firm value -as reflected by Tobin's Q, book-to-market value of the firm- increases in the years following the vote. We interpret these results as evidence that firms are operated differently as a result of their improved corporate governance structure, reflecting changes in managers' behavior. Finally, the effect that we identify is, by definition, only for firms that have observations around the discontinuity, and this determines how much one can extrapolate the results of our analysis to other firms. However, we show that firms that have observations falling around the threshold are not very different from other firms that are targets, and that $35 \%$ of the G-index proposals fall within ten percentage points of the majority threshold. This suggests that our results can be directly generalizable to a sizeable set of firms, though not to all.

The next section describes the data and presents an analytical framework of how the information on the stock-price reaction to the outcome of governance votes that fall around the majority threshold allows us to recover the effect of governance proposals. Section III presents the empirical model used to identify this effect. Section IV provides evidence on the regression discontinuity in shareholder votes as a quasi-experiment. Section V presents the results, and Section VI concludes.

\section{Shareholder votes and abnormal returns}

\subsection{Data description}

To estimate the value of governance proposals, we use data collected by Riskmetrics on shareholders' proposals from 1997 until 2007. ${ }^{5}$ Our sample includes all 3,984 shareholder proposals Riskmetrics

\footnotetext{
${ }^{5}$ Rule $14 a-8$ permits shareholders to submit proposals requesting that certain corporate matters be put to a vote at the company's next annual meeting. To be eligible to submit a proposal, a shareholder must be a beneficial owner of at least $1 \%$ or $\$ 2,000$ in market value of securities entitled to vote, have owned these securities for at least one
} 
classifies as governance-related and that are included in the proxy statement for all S\&P 1,500 companies plus an additional 500 firms that are widely held (Appendix A shows the full list of proposals and how frequently each of them appears in the data). Riskmetrics provides data on the company name, the date of the annual meeting, the percentage of votes in favor of the proposal, the description of the type of proposal, and the proponent. ${ }^{6}$ Most shareholder proposals are presented as a recommendation to the board of directors - that is, the outcome of the vote is non-binding. Ertimur, Ferri and Stubben (forthcoming) show that $31.1 \%$ of the shareholder proposals that pass are implemented, while only $3.2 \%$ of those not approved are implemented.

Riskmetrics classifies the proposals into 72 distinct types. While the effect of the different types of proposals is probably heterogeneous, we bundle them into broader categories due to the limited number of observations in each group. For descriptive purposes, we group these governance proposals into six categories widely used in the literature: anti-takeover proposals (G-index), compensation, voting, auditors, board structure and other (see Appendix A). Panel A of Table 1 displays the frequency of governance proposals, the percent approved and the average support over time. From 2003 onwards, there is a significant increase in the number of proposals, over 400 cases per year, and around $30 \%$ of those are approved. Panel B also shows that G-index proposals obtained the highest levels of shareholder support and were approved in $53 \%$ of the cases. Compensation proposals were approved only in $4.2 \%$ of the cases, board structure in $8.8 \%$ and voting proposals in $3.3 \%$. For the empirical analysis, the difference in approval rates means that we have very few observations on compensation, board structure or voting around the discontinuity, so we will have to further pool all those proposals and analyze them together. Appendix A shows the number of proposals of each type falling around the majority threshold. Among the 523 G-Index proposals within 5 percentage points of the discontinuity, 219 (42 percent) are proposals to repeal classified boards, and 132 (25 percent) are proposals to eliminate poison pills. Among the 387 Other (non-Gindex) kinds of proposals around the discontinuity, 115 (or 30 percent) are proposals to elect directors through a majority vote, and 68 (18 percent) are proposals to expense stock options. Throughout the paper, we analyze two sets of proposals (G-index vs. Other) both pooled and separately.

For the 948 firms that constitute our final sample, we obtained additional information from a

year, and continue to own them through the date of the meeting.

${ }^{6}$ We checked that all the proposals go in the direction of increasing shareholder rights and control, or improving alignment. We also used a second Riskmetrics dataset with information on whether majority is computed out of votes cast or outstanding, and on the majority threshold. Most proposals have a $50 \%$ majority threshold, three had a $66.7 \%$ threshold, three had a $70 \%$ threshold and four had an $80 \%$ threshold. We also used this dataset to check that the vote was correctly recorded. In the cases where we found discrepancies between the two datasets, we looked at the company statements. 
number of different sources: security prices from CRSP; financial information from Compustat; data on acquisitions from the SDC database; and institutional ownership characteristics from Thomson Financial. ${ }^{7}$ Table 2 displays the characteristics of the firms in our sample.

\subsection{Identifying shareholder returns from votes on governance proposals}

In this section, we present an analytical framework that shows how to recover the value of a governance provision by focusing on close votes in shareholder-sponsored governance proposals. Figure 1 provides an illustration. Denote $v$ as the vote share in favor of passing a proposal, and $W(v)$ as the value to the firm of a particular vote outcome. For simplicity, we assume throughout this illustration that the outcome of the vote is always binding, that the majority threshold for a vote to be approved is $v \geqslant 50 \%$, and that the value of the proposal to the firm is fixed (i.e., independent of $v$ ), such that $W(v)=\bar{W}$ if $v \geqslant 50 \%$ and zero otherwise. Figure 1 represents $W(v)$ and shows the change in the underlying value of the firm after the vote. The objective of the empirical analysis is to estimate $\bar{W}$, the value of implementing a governance proposal, which is not directly observable. As the day of the vote approaches, investors use all the available information to form an expectation of the probability that the proposal will succeed, and this expectation is incorporated in stock prices. Therefore, the price reaction -the abnormal return- that we observe when the outcome of the vote is known is the difference between the actual value of the proposal to the firm $W(v)$ (which is either $\bar{W}$ or 0 , depending on whether it passes or not) and its expected value before the vote (the average price that the market had formed for a given observed vote outcome), $E(W \mid v) .{ }^{8} E(W \mid v)$ is represented by a dashed line in Figure 1. The intuition behind $E(W \mid v)$ is that for votes that have a vote share $v$ close to zero, the market had already assigned a low probability that they would pass, and, therefore, $E(W \mid v)$ is close to zero. Similarly, for votes around $100 \%$, the market assigned a high probability of passing and $E(W \mid v)$ is close to $\bar{W}$. In contrast, around the threshold, the market had assigned a roughly $50 \%$ probability that the vote would pass and $E(W \mid v)$ is close to $\frac{1}{2} \bar{W}$.

Since $E(W \mid v)$ is a continuous function of $v$, but $W(v)$ is discontinuous at the majority threshold, the abnormal return that one observes when the outcome of the vote is known is also discontinuous

\footnotetext{
${ }^{7}$ Most of these datasets are recorded at the end of the fiscal year. To determine what is the first observation after a vote, we require that the end of the fiscal year is at least six months after the meeting where the vote is recorded. If it is less than six months, then we use the following year available as the first year after the meeting.

${ }^{8}$ See supplemental Appendix for details on how to derive $E(W \mid v)$ analytically.
} 
at the majority threshold. In fact, the difference in abnormal returns at the majority threshold $-Z$ in Figure 1- between a vote that barely fails and one that barely passes is exactly the value of the proposal. Under the set of assumptions outlined earlier: $Z=(\bar{W}-E(W \mid v))-(0-E(W \mid v))=\bar{W}$. Therefore, one can recover the value of the proposal from the difference in abnormal returns of close-call votes or, in other words, at the discontinuity.

The earlier example made a number of assumptions that may not necessarily hold in reality. In practice, shareholder proposals are typically not binding. A proposal may pass but not be implemented; thus $W(v)$ will be below the effective value of the proposal to the right of the threshold, and the market reaction to proposals that pass by a close margin will be less positive than if the vote were binding. Similarly, if management feels that a proposal that fails to pass by a few votes should still be implemented, $W(v)$ will be slightly positive to the left of the threshold and the market reaction will be less negative. Furthermore, $W(v)$ may incorporate the probability that the current vote will trigger another proposal in the future that, in turn, may or may not pass. As a result, $E(W \mid v)$ and abnormal returns are not necessarily symmetric around the threshold, as in our simple example in Figure 1. Still, provided $E(W \mid v)$ is continuous and the probability of implementation discontinuous around the threshold, then $Z$ can be used to measure the value of the proposal to the firm. In this case, the value estimated at the discontinuity, $Z$, is not equal to $\bar{W}$, as in the previous example (Supplemental Appendix Figure SA5 illustrates this case). In order to recover the value of $\bar{W}$ from our estimate $Z$, we need to consider that, around the discontinuity, the market is updating both the probability of implementation and the chances of proposing and passing future proposals.

Note that our identification strategy does not require proposals to be binding. As discussed in Lee and Lemieux (forthcoming), the identification strategy is still valid as long as there is a discrete jump in the probability of implementation at the majority threshold (this is the "fuzzy" regression discontinuity setting). ${ }^{9}$

We can define $p^{I}$ as the difference in the probability of implementation of a proposal that passes by a short margin relative to one that fails by a short margin. Similarly, we can define $p_{t+i}^{p}$ as the endogenous change in the probability of passing and subsequently implementing another proposal $i$ periods from now (as a result of the current proposal passing at the discontinuity). Assuming a discount rate of $\delta^{i}$, the market reaction at the threshold $Z$ can, therefore, be written as the sum of two elements: the value associated with the current proposal being implemented, $\left(p^{I} \bar{W}_{f}\right)$, plus

\footnotetext{
${ }^{9}$ In Ertimur, Ferri and Stubben (forthcoming), the change in the probability of implementation at the majority threshold can be inferred to be around of $20.7 \%$; and in section 5.1.3, we estimate a discrete change in the implementation probability of $30.1 \%$ within two years for the subset of proposals that affect the G-index .
} 
the present discounted value of future proposals being passed and implemented as a result of the current proposal passing $\left(\sum_{i=1}^{\infty} \delta^{i} p_{t+i}^{p} \bar{W}_{f}\right)$. So, once we obtain estimates $p^{I}, p_{t+i}^{p}$ from the data, the value of the proposal can be recovered as:

$$
\bar{W}_{f}=\frac{Z}{p^{I}+\sum_{i=1}^{\infty} \delta^{i} p_{t+i}^{p}} .
$$

One important question that arises when trying to infer the value of a proposal from the abnormal returns at the discontinuity is whether we should expect any effect at all of votes that barely pass or fail. Shareholder votes should reflect a value-maximizing decision. If all shareholders were trying to maximize shareholder value, and in the absence of transaction costs, then they should all vote in the same way, in favor of or against a proposal. If shareholders are identical but have different information on the value of a proposal, then some votes would fall around the discontinuity, and those would correspond to proposals whose value to the firm is neutral or uncertain. However, when the objective of some shareholders is not to maximize shareholder's value (say, in the presence of other private benefits), then the outcome of the vote will depend on the distribution of their preferences. In this sense, it is well-documented that different types of shareholders vote differently because they are heterogeneous in their objectives, and may have other stakes in the firm. For example, it has been shown that banks and insurance companies tend to side with management by voting against the proposals, while mutual funds, unions, advisors and pension funds tend to support the proposals (Brickley, Lease and Smith, 1988; Agrawal, 2008). The fact that we find positive abnormal returns at the discontinuity suggests that there are decisions that maximize shareholder value but are hard to implement given the ownership patterns of firms.

\subsection{Abnormal returns as a function of the vote share: graphical evi- dence}

Figure 2 shows the impact of passing a proposal on shareholder abnormal returns on the day of the meeting. The daily abnormal returns were calculated from CRSP using the three Fama-French factors and the momentum factor from Carhart (1997). ${ }^{10}$ It is the empirical counterpart of Figure 1, although note that since, in practice, vote outcomes are not binding and may trigger future

\footnotetext{
${ }^{10}$ These three factors are standard in the literature and adjust for different sources of risk that should affect daily returns, including the market factor (excess market return), a size factor, and a factor that accounts for the security being a value or growth stock (using book to market). The estimation period starts two months prior to the event date; the length of the estimation period is 200 trading days, and we impose at least 15 days with returns to make it into the sample.
} 
proposals, this can make the effects non-symmetric around zero. The graph plots the average daily abnormal return for the day of the meeting $(t=0)$ when the information of the vote is revealed. The $\mathrm{X}$-axis reflects the margin of victory (the vote share minus the threshold for that vote). On the day of the vote, proposals that pass by a small margin have positive abnormal returns, and comparing those to proposals that fail by a small margin gives us the effect of passing a proposal on abnormal returns. Notice that proposals that pass by more than a 5\% margin display zero abnormal returns, which is consistent with the fact that the market can forecast with some accuracy the probability of passing a proposal, and this is incorporated in prices. Most firms disclose vote outcomes on the same day of the annual meeting through a variety of channels (news wires and real-time broadcast). Independently, institutional investors such as CALPERS provide news posts on voting results. Additional information is released by the media covering these corporate events.

Figure 2 is an intuitive representation of the main result of the paper: close-call governance proposals that pass lead to positive abnormal returns on the day of the vote, while those that do not pass lead to negative or negligible ones. Before showing regression results in section 5, over the next two sections, we describe the methodology that uses all the data efficiently and we test the validity and generality of our approach.

\section{Methodology and identification strategy}

This section describes how we can estimate the causal effect of shareholder governance proposals on shareholder returns and other outcomes using a regression discontinuity (RD) setting.

\subsection{Regression discontinuity in shareholder votes}

Suppose that shareholders of firm $f$ vote on a shareholder proposal at time $t$, the meeting date, and that this proposal gets a total vote share (percentage of votes in favor) $v_{f t}$. If $v_{f t}$ is larger than the majority threshold $v^{*}$, then this proposal passes and we code the indicator for pass as $D_{f t}=1\left(v_{f t} \geqslant v^{*}\right)$.

We are interested in the effect that passing a certain proposal has on an outcome variable $y_{f t}$. Then, we can write:

$$
y_{f t}=\kappa+D_{f t} \theta+u_{f t}
$$

where the coefficient $\theta$ we are interested in is the effect of passing a proposal in a shareholder 
meeting on the outcome variable $y_{f t}$-say, abnormal returns, or the probability of future proposals passing- and $u_{f t}$ represents all other determinants of the outcome $\left(E\left(u_{f t}\right)=0\right)$. The problem with estimating a regression such as (2) directly is that the passage of a proposal is a highly endogenous outcome, and $D_{f t}$ is unlikely to be independent of the error term $\left[E\left(D_{f t}, u_{f t}\right) \neq 0\right]$, such that the estimate of $\widehat{\theta}$ will be biased.

To get a consistent estimate, we would ideally want "passing" a proposal to be a randomly assigned variable. The regression discontinuity framework that exploits the vote shares helps us approximate this ideal setup because in an arbitrarily small interval around the discontinuity (the threshold $v^{*}$ ), whether the proposal passed or failed is random (e.g., whether a proposal passes by $50.1 \%$ or fails by $49.9 \%$ is random). Lee (2008) formally shows that, as long as there is a random component to the vote, the assignment into "treatment" (pass and $D_{f t}=1$ ) and "control" groups (fails and $D_{f t}=0$ ) is random around the threshold. ${ }^{11}$ This implies that our estimate of $\widehat{\theta}$ using the regression discontinuity design is immune to bias from omitted variables - such as firm announcements- even if they are correlated with the vote, as long as their effect is continuous around the threshold. Therefore, by comparing the outcome $y_{f t}$ of votes that barely passed to the outcome of votes that barely failed, we get a consistent estimate of the value of a new governance rule.

In order to use all our data and improve efficiency, we follow the standard approach (see Lee and Lemieux, forthcoming) and assume that we can approximate the underlying relationship between $y_{f t}$ and $v_{f t}$, with a polynomial in the vote share. This polynomial flexibly captures the underlying relationship between the vote share and the outcome variable, such that any discontinuous jump at the threshold is captured by $\theta$. Allowing for a different polynomial for observations on the right-hand side of the threshold $P_{r}\left(v_{f t}, \gamma^{r}\right)$ and on the left-hand side of the threshold $P_{l}\left(v_{f t}, \gamma^{l}\right)$ gives:

$$
y_{f t}=D_{f t} \theta+P_{r}\left(v_{f t}, \gamma^{r}\right)+P_{l}\left(v_{f t}, \gamma^{l}\right)+u_{f t}
$$

This estimate, $\widehat{\theta}$, is precisely the estimate of $Z$ from section 2.2 (Figure 1 ). Therefore, when $y_{f t}$ are abnormal returns, the regression discontinuity model yields a consistent estimate of $Z$.

\footnotetext{
${ }^{11}$ This random component contains all kinds of random events that affect the voting outcome. It does not need to be large for our purposes, given that we perform a local analysis.
} 


\subsection{Panel data, multiple votes and multiple shareholder meetings}

Two issues emerge when trying to implement the standard RD model of equation (3) to analyze the effect of governance rules in our data. The first is that there is a dynamic component to our data that implies that elections at time $t$ will have an impact on outcomes at times $t+1, t+2$, etc. The second is that for each firm and meeting date, shareholders may have to vote on more than one governance issue (the average number of shareholder governance proposals voted on in a meeting in our sample is 1.64), so we need to find a way to aggregate all votes by firm and meeting date.

\subsubsection{Dynamics in the impact of the votes}

We follow the empirical model in Cellini et al. (2010) to characterize the dynamic version of the $\mathrm{RD}$ for a firm $f$ that has a vote at time $t$, and we define the outcome $\tau$ periods later $y_{f, t+\tau}$ as:

$$
y_{f, t+\tau}=D_{f t} \theta^{\tau}+P_{r}\left(v_{f t}, \gamma_{\tau}^{r}\right)+P_{l}\left(v_{f t}, \gamma_{\tau}^{l}\right)+u_{f t, t+\tau}
$$

$\theta^{\tau}$ estimates the causal effect of passing a vote at time $t$ on outcomes at $t+\tau$. Estimating equation (4) separately for each period $t+\tau$, as noted by Cellini et al. (2010), is inefficient because there is an important component that is fixed within firms over time but varies across firms. We follow their strategy, pooling data for multiple $\tau$ (including $\tau<0$ ) and including controls to absorb firm-level heterogeneity. For each election in our data $(f, t)$, we use observations for firm $f$ in periods $t-2$ to $t+T$ ( $T$ is up to seven days after the election for abnormal returns and four years after the election for other outcomes). We then estimate:

$$
y_{f, t+\tau}=D_{f t} \theta^{\tau}+P_{r}\left(v_{f t}, \gamma_{\tau}^{r}\right)+P_{l}\left(v_{f t}, \gamma_{\tau}^{l}\right)+\alpha_{\tau}+\eta_{c}+\lambda_{f t}+e_{f t \tau}
$$

This follows equation (7) in Cellini et al. (2010) (see, also, more details for the sample construction in that paper). ${ }^{12} \alpha_{\tau}, \eta_{c}$ and $\lambda_{f t}$ are fixed effects for time periods relative to the meeting date, calendar years and focal elections, respectively. $\theta^{\tau}, \gamma_{\tau}^{r}$ and $\gamma_{\tau}^{l}$ are allowed to vary for $\tau \geqslant 0$, and constrained to zero for $\tau<0$, and standard errors are clustered by firm $f$. Here, $\theta^{\tau}$ is the effect of passing a proposal at time $t$, on outcomes $\tau$ periods later, and we obtain separate estimates for the contemporaneous effect $(\tau=0)$, one period later $(\tau=1)$, etc. Notice that this dynamic model

\footnotetext{
${ }^{12}$ This yields the Intent To Treat (ITT) estimator in Cellini et al. (2010). That paper also demonstrates how to derive Treatment On the Treated (TOT) estimates in the dynamic regression discontinuity setting. For our daily shareholder return regressions, ITT and TOT are identical since there is only one election per year and, hence, no intervening elections between $t$ and $t+7$, when $t$ is measured in days.
} 
allows us to introduce focal meeting fixed effects $\lambda_{f t}$, and those will absorb any characteristic of the meeting that affects outcomes in periods $t+\tau$ (e.g., characteristics of the firm that are constant during the event window). Information is mostly released on the day of the vote, but, in any case, this dynamic structure would capture any effect in subsequent days.

\subsection{Aggregating votes}

Next, we need to find a way to aggregate all votes for a given firm and meeting date. To illustrate how we do this, we first ignore dynamics and use the simple (non-dynamic) equation (3). Imagine that the firm could vote on two issues, A and B, on any given date. Then, we would extend equation (3) to allow for two different kinds of votes to affect $y_{f t}$ :

$$
y_{f t}=D_{f t}^{A} \theta^{A}+D_{f t}^{B} \theta^{B}+P_{r}^{A}\left(v_{f t}^{A}, \gamma^{A, r}\right)+P_{r}^{B}\left(v_{f t}^{B}, \gamma^{B, r}\right)+P_{l}^{A}\left(v_{f t}^{A}, \gamma^{A, l}\right)+P_{l}^{B}\left(v_{f t}^{B}, \gamma^{B, l}\right)+u_{f t},
$$

and $\theta^{A}\left(\theta^{B}\right)$ would be the effect of proposals of type A (B) on the outcome of interest. The problem is that there are not just two types of governance proposals but 72 (see Appendix A). Given that we identify effects only around the discontinuity, the number of observations limits how much we can separate out the effects. However, under the assumption that for all $A$ and $B: \theta^{A}=\theta^{B}=\theta$; $P_{r}^{A}=P_{r}^{B}=P_{r}$; and $P_{l}^{A}=P_{l}^{B}=P_{l}$ we can rewrite equation (3) as:

$$
y_{f}=\theta \sum_{K=1}^{N} D_{f t}^{K}+\left[P_{r}\left(\sum_{K=1}^{N} v_{f t}^{K}, \gamma^{K, r}\right)+P_{l}\left(\sum_{K=1}^{N} v_{f t}^{K}, \gamma^{K, l}\right)\right]+u_{f t} .
$$

And $\theta$ is the average causal effect of a proposal. In order to allow for more flexibility than this arguably restrictive but practical assumption allows, we will allow $\theta$ to vary by two relevant groups of proposals (anti-takeover provisions vs. other proposals). We will also let the effect of $\theta$ be non-linear in the number of proposals passed and, as we will see, the effect is approximately linear. Unfortunately, the number of observations that are around the discontinuity limits how flexible we can be in allowing for more disaggregated groups. When we restrict our analysis to meetings where only one governance proposal is voted on (and, therefore, we do not need to aggregate across proposals), we obtain results similar to those using multiple votes in a day; thus, equation (6) appears to be a good way to summarize the data.

When we put together equations (5) and (6), which recognize the dynamic structure of the data 
and the need to aggregate over $N$ proposals, we obtain our estimating equation:

$$
y_{f, t+\tau}=\theta^{\tau} \sum_{K=1}^{N} D_{f t}+\left[P_{r}\left(\sum_{K=1}^{N} v_{f t}^{K}, \gamma_{\tau}^{K, r}\right)+P_{l}\left(\sum_{K=1}^{N} v_{f t}^{K}, \gamma_{\tau}^{K, l}\right)\right]+\alpha_{\tau}+\eta_{c}+\lambda_{f t}+e_{f t \tau}
$$

Throughout the paper, we use a polynomial of order four on either side of the threshold (Supplemental Appendix, Table A shows that our results are robust to the use of higher-order polynomials).

\section{Election votes as a quasi-experiment: vote distribution and pre-existing differences}

The basic assumption of the regression discontinuity design is that around the threshold, passing a proposal is as good as random assignment. Here, we provide a standard test of this assumption that consists in evaluating whether the distribution of votes is continuous around the majority threshold. Figure 3 shows the distribution of the vote share (the percentage of votes in favor) for all votes in our sample. If there were sharp changes in that distribution around the threshold, this would indicate that the probability of falling on either side of the threshold is discontinuous and that the main identification assumption is likely not to hold (McCrary, 2008). Figures 4 and 5 show the distribution of votes separately for proposals to remove anti-takeover provisions (those included in the G-index), and Other proposals to increase shareholder control (including compensation, board-related and auditor-related proposals). In these, we also see that the distribution is smooth around the threshold. ${ }^{13}$ Listokin (2008) also reports a smooth distribution of shareholder-sponsored proposals around the majority threshold as evidence of lack of strategic behavior. In contrast, he shows that management proposals (which are excluded from our analysis) display a very sharp discontinuity in the density of votes at the majority threshold; essentially, these rarely fail to pass, as management strategically withdraws those proposals that are likely to fail.

Figures 4 and 5 also show that anti-takeover proposals are more likely to fall around the discontinuity. Since our estimates are identified only from observations around the discontinuity, this implies that most of the effect we estimate comes from the passage of anti-takeover provisions. It also limits the extent to which we can try to identify the effects of different subgroups since we do not have enough observations around the threshold.

\footnotetext{
${ }^{13}$ We performed the density test for smoothness of the vote share suggested in McCrary (2008) and could not reject smoothness around the majority threshold. [See Supplemental Appendix Figures SA2 to SA4].
} 
A second standard test of the regression discontinuity design consists in evaluating whether prior to the day of the vote, there were systematic differences in the characteristics of firms that fall on either side of the threshold. If one found systematic differences in characteristics of firms that just pass, relative to those that just fail to pass a proposal, then the main assumption of the design is likely to be violated. The first column in each panel of Table 3 looks at firms where a proposal passes and those where a proposal fails and evaluates whether there is a difference in a number of firm characteristics in the period before the meeting. The regressions in column 1 do not control for a polynomial in the vote share, so that they estimate the average pre-difference in characteristics across all firms. The regressions in column 2 include the polynomials of order four on either side of the threshold, so that they estimate the effect at the discontinuity. We see that there is no significant difference in abnormal returns on the day before the meeting (Panel A) or in Tobin's Q, capital expenditures, return on equity or R\&D over assets in the year before the meeting (Panel B). There is no difference in the growth rates of those variables, on average (column 3), and most importantly for our identification, around the discontinuity (column 4), which indicates the absence of pre-existing differences. Panel $\mathrm{C}$ examines two acquisitions variables (number and value of acquisitions), and neither has significant differences around the threshold.

Next, we examine differences in ownership concentration for institutional owners (Panel E). As mentioned, the presence of institutional owners is likely to be a determinant of the outcome of the vote. In column 1, Panel E, we find that, indeed, a proposal is more likely to pass in firms with a high reported concentration of institutional owners (measured as the sum of institutional ownership for the top five shareholders in the last fiscal quarter before the meeting) or with more institutional owners that report to own at least $5 \%$ of shares outstanding. ${ }^{14}$ This confirms the fact that one cannot directly compare firms with or without governance provisions in place since these are different kinds of firms. However, once we include the polynomial in the vote share in column 2 of Panel D, we see that there is no significant difference around the threshold, which lends support to our identifying assumption.

Similarly, one expects that firms with different levels of shareholder rights, as measured by the G-index, have different propensities to pass shareholders' governance proposals. Column 1 of Panel E shows that firms with a higher G-index (more anti-takeover provisions in place) are more likely to pass the shareholder proposals. However, firms around the vicinity of the discontinuity do not differ along this dimension, which further supports the paper's basic identifying assumption. Finally,

\footnotetext{
${ }^{14}$ These two variables are computed using SEC Form 13F quarterly filings, provided by Thomson Financial.
} 
we also examine a number of additional meeting characteristics such as the number of proposals, the number of withdrawn proposals prior to the annual meeting and the identity of the proponent and find no evidence of pre-existing differences at the discontinuity (see Table B in Supplemental Appendix).

Overall, our results show that there is no evidence of selection into either side of the discontinuity, based on observable variables.

\section{Results}

\subsection{Market reaction to exogenous changes in governance}

\subsubsection{The effect of governance proposals on abnormal returns}

Table 4 shows estimates of the difference in abnormal returns between proposals that pass and proposals that do not pass for increasingly small intervals around the election threshold on the day of the vote (standard errors are clustered by firm). Column 1 estimates this on the whole sample, and we find that, as expected, there is no difference, on average, between those passing and those failing (a highly insignificant estimate of 0.0009) since the market incorporates the expectation in the prices. Column 2 restricts the sample to within ten percentage points of the threshold, and here we begin to see a higher estimate (0.002- i.e., $0.2 \%$ daily abnormal return) and a smaller standard error. For votes within five percentage points of the threshold, the abnormal return is $0.76 \%$ higher for those that passed (and this is significant at 1\%), and as we narrow the window even further to two percentage points (column 4) and one percentage point (column 5), the abnormal return of passing increases to $1.05 \%$ and $1.39 \%$, respectively. These are still significant, even though the number of observations falls as we narrow the window. Panels B and C of Table 4 show the same set of regressions for anti-takeover provisions and all other proposals pooled, respectively. We find a similar pattern, with most of the effect being driven by anti-takeover provisions. This is partly because there are more G-index proposals that fall around the discontinuity, so we can estimate them more precisely. It also reflects the fact that G-index proposals are thought to have a potentially more important impact in insulating managers to pursue their private goals. Within one percentage point of the interval, passing an anti-takeover provision yields a $2.2 \%$ abnormal return on the day of the vote.

Finally, column 6 makes use of all the data in the sample (as described in section 3.1) and introduces two polynomials of order four in the vote share, one on each side of the threshold (as in 
equation (3) above). Using this model, we estimate that the effect of passing a proposal is $1.3 \%$, which is very close to the results of the unrestricted models of the earlier columns.

Figure 6 shows the day-by-day difference in abnormal returns between firms where a proposal passes or fails within five percentage points on either side of the majority threshold. We observe a clear peak in the difference in returns between firms that pass and firms that do not pass a proposal on the day of the vote, $t=0$ (this is the same as the coefficient in column 3 of Table 4, Panel A). For other days around the annual meeting, there are no clear spikes or discernible pattern. This shows that the market incorporates the outcome of the vote on the day of the vote itself - when the outcome is known- and not before. It also seems that there are no further additional returns on the days after the vote.

Table 4 is a simple and transparent representation of our data, but it does not take into account that several proposals can be voted on in one day; that the effect of the vote could potentially persist over more than one day; or that the returns are likely to be correlated over time, given that they respond to the same events. In order to incorporate these characteristics of the data, we use the full model described in equation (7). The results are shown in Table 5. Column 1 displays the effect of passing a proposal on the meeting date $(t)$, the day after $(t+1)$ and the cumulative effect from $t+2$ to $t+7$. We find that most of the effect $(1.3 \%$ abnormal return) is on the day of the vote, when the surprise around the threshold occurs. The following days yield around $0.2 \%$ daily abnormal returns, but these are insignificant. Column 2 shows similar results using a different model to compute the daily abnormal returns (a standard one-factor market model instead of the three-factor Fama-French with momentum that we use in the rest of the analysis).

Overall, we find that most of the effect on prices occurs on the day of the vote. In column 3 , we explore further what happens on that day by allowing for a more flexible specification of the effect of the number of votes on daily returns (recall that the model in equation (7) sums over the votes of the day to aggregate over all the different outcomes). Here, we allow for different dummy variables for the number of proposals that passed, with a maximum of six proposals passing in a given meeting day. We find that the effect is monotonically increasing and approximately linear in the number of proposals, such that the model in Section 3.3 is appropriate (the effect of passing one proposal is $1.3 \%$, similar to our baseline estimate; passing two proposals yields a $2.2 \%$ abnormal return; three and four proposals yield a total of $4.6 \%$ returns, etc.). Columns 4 and 5 allow for a different effect of the two kinds of proposals: the set of anti-takeover provisions included in the G-index and the set of Other proposals. Among these Other (non G-index) proposals, the ones that 
fall more frequently around the discontinuity are proposals to increase board independence from management and proposals to expense stock options (see Appendix A). We confirm that most of the effect is driven by anti-takeover proposals -in particular, by proposals to repeal a classified board and to eliminate poison pills (see Appendix A). However, we also find positive, albeit somewhat smaller and less precisely estimated effects of other kinds of proposals, which have received less attention in the literature.

In sum, we find that there is a significant $1.3 \%$ average price reaction to proposals that pass by a small margin relative to those that fail by a small margin. ${ }^{15}$ We argue that the regression discontinuity design allows us to obtain a causal estimate, that is not driven by omitted variables, unobserved firm characteristics or other events. The positive price reaction on the day of the vote may reflect the idea that the governance improvement will lead to lower agency costs and higher firm value; or it could also reflect a takeover premium. In Section 5.3 below, we study the long-term effects of these votes to assess the evidence on these different possible explanations for the positive price reaction.

\subsubsection{Heterogeneous effects of governance proposals}

It is likely that firms with different characteristics may have different quantitative responses to passing a governance proposal. To further investigate this potential heterogeneity in responses, we study the effect of governance proposals in different subsets of the data. In particular, we analyze the differential response in firms according to the level of concentration of the top five institutional owners, the intensity of anti-takeover protection in place at the time of the meeting (G-index), and whether the firms had high R\&D expenditures.

We find that firms with a higher concentration of large institutional owners respond more to passing a provision than do firms with more-dispersed ownership. In particular, column 1 of Table 6 , shows that passing a shareholder proposal in concentrated-ownership firms elicits a $2 \%$ abnormal return on the day of the meeting, with a further cumulative $2.3 \%$ in the seven days after the meeting (for G-index proposals -column 4- the cumulative return over seven days is $3.6 \%$ in concentratedownership firms). This may reflect that these firms are more closely monitored and, therefore, the proposal is more likely to be implemented, or that the value of these provisions is higher for these firms -and that governance proposals and monitoring are complements in the governance structure. We also find that firms with many anti-takeover provisions benefit more from the removal of takeover

\footnotetext{
${ }^{15}$ This is a large and significant effect in contrast with the generally small or insignificant results found when using the mailing date as an event study (See Gillan and Starks, 2000; Thomas and Cotter, 2007).
} 
barriers. In firms with more than ten (median) G-index provisions in place on the day of the meeting, passing a G-index shareholder proposal yields a 1.9\% abnormal return on the day of the vote and a further $2.4 \%$ in the following seven days (column 5 ).

The previous analysis shows that, on average, passing a proposal that improves shareholder rights increases shareholder value. However, it is possible that having excessive shareholder rights in place can be detrimental to firms if that leads managers to focus excessively on the short run at the expense of the long run (Stein, 1988). If this were true, firms in which long-run investments are important might respond negatively to these governance proposals. We proxy the long-term nature of firms' investment by their R\&D expenditures. Columns 3 and 6 estimate our basic model for firms with above-median R\&D-to-assets ratio prior to the meeting. We find, in fact, that the effect for these firms $(1.6 \%)$ is very similar to the result for the whole sample $(1.3 \%)$, indicating that there is no different response, at least along this dimension of long-run investment needs, and that the change in abnormal returns from changes in the governance structure is also positive for these firms.

Finally, the regression discontinuity estimate is, by construction, the weighted average effect across all firms and proposals, where more weight is given to those votes in which a close election was expected (Lee and Lemieux, forthcoming). In our case, as mentioned, the elimination of staggered boards and poison pills represent $68 \%$ of G-index proposals falling around the discontinuity, implying that those have a bigger weight in the identification.

In terms of how much one can extrapolate the results of our analysis to other firms, one must take into account that, within listed firms, those that are larger, less profitable and have a higher level of institutional ownership tend to be targeted by shareholder proposals more often (Karpoff et al., 1996; Romano, 2001). However, within the set of firms that are the target of a proposal, we know from Section 4 that there are no systematic differences between firms on either side of the threshold which means there is no evidence of selection into treatment. We also can see in Figure 4 that the mass of G-Index proposals actually is around the majority threshold. Still, firms with votes around the threshold may be different from other firms in our sample. In order to have a sense of what kinds of firms have observations that fall around the discontinuity, we plot the distribution of institutional ownership and of Tobin's Q in the year before the meeting for (i) firms that have a vote share lower than 45\%; (ii) firms that have between $45 \%$ and $55 \%$ votes in favor-those falling around the discontinuity; and (iii) firms with more than $55 \%$ of votes in favor. Figures 7 and 8 show that firms with vote shares around the discontinuity fall roughly in between firms in the other 
two groups (e.g., the distribution of institutional ownership for proposals in the G-index is between the other two groups, and so is the distribution of Tobin's Q -Figure 7). Even though one cannot immediately generalize our results to all firms, the evidence suggests that firms that fall around the discontinuity are not "extreme" observations, but, rather, firms with average characteristics.

\subsubsection{Implementation and the probability of passing future proposals}

While we do not have information on whether each proposal in our data was implemented, we know how the value of the G-index changes over time for most firms in our sample. The G-index is the number of anti-takeover provisions in place at a point in time. We can evaluate how it responds to the passage of a provision at the discontinuity. This serves as a proxy for implementation. Column 1 of Table 7 shows the effect of passing a governance proposal on the G-index. The index is available only every two years, so the first coefficient is the effect on the first year available after the focal meeting (this can be between one and two years after the meeting, depending on when the vote occurred relative to the G-index years), and the second coefficient is two years later, etc. We find that the probability of implementation increases discretely around the discontinuity; thus, proposals that pass by a small margin are substantially more likely to be implemented relative to those that fail. Passing a proposal reduces the G-index by 0.313 , which we interpret as a $31.3 \%$ probability of removing an anti-takeover provision within two years. That number grows in subsequent years, and within four years, the probability is $50 \%$. This indicates, in part that when a proposal is passed but not implemented, shareholders are likely to propose it again. Our estimates are consistent with the results in Ertimur et al. (forthcoming).

Passing a governance proposal in a given meeting is also likely to affect the probability of submitting and passing other proposals in the future. Ex-ante, it is unclear whether it will increase, decrease or have no effect on those future probabilities. We assess these dynamic effects in our data using equation (8) and, as the dependent variable, the number of proposals that are submitted and passed in each year. The variable is zero if there are no shareholder governance proposals, or if these do not pass. Table 8 shows the results. Column 1 includes the polynomial in the vote share and shows that, around the discontinuity, passing a G-index proposal leads to 0.325 more proposals being passed the following year and 0.119 more two years later, and the positive effect declines and becomes insignificant after year four. The effect for other proposals is generally insignificant, or negative. The dependent variable in column 2 is the number of G-index proposals passed in each year, and the results indicate that the effect in column 1 is driven mainly by G-index proposals. This 
is an important set of results that shows there is a substantial dynamic element to these proposals, with passing G-index proposals making it more likely that other proposals will be passed in the future.

\subsection{The value of a governance proposal}

In the previous section, we found that passing a provision increased shareholders' returns on the day of the vote by $1.3 \%$. This is our estimate of $Z$, as defined in Section 2.2. However, we know that the observed abnormal return is not the full expected increase in value from implementation. It is an expectation that accounts for the probability that the proposal will be implemented, plus further effects of submitting and implementing governance proposals in the future. In order to recover the actual value of a proposal, $\bar{W}$, using equation (2), we need to know (i) the probability that the provision is implemented if passed, and (ii) the probability that other proposals will be passed and implemented in the future.

We obtain estimates for these probabilities in two different ways. The first is using the results from Table 7 with the G-index as a proxy for implementation. In the previous section, we showed that passing a proposal reduces the number of G-index provisions by 0.31 . We also found that two years later, the probability of implementation is 0.016 higher (0.329-0.313), and two years after that, it is 0.174 higher (0.503-0.329), etc. With these probabilities in hand and assuming a discount rate of $5 \%$, we can use equation (1) to recover the value of a provision to the firm. We estimate that to be a $2.8 \%$ increase in market value.

As a second way to determine the value of a provision, we use different sources for the estimated probabilities that feed into equation (1). Ertimur et al. (forthcoming) find a 20.7\% discrete change in the probability of implementation at the threshold $\left(p^{I}\right) .{ }^{16}$ The probability that a proposal will be implemented in the future $\left(p_{t+i}^{p}\right)$ is equal to the probability that it will pass in the future times the probability that it will be implemented conditional on passing. The average probability that a proposal that passes will be implemented is $31.1 \%$ (Ertimur et al., forthcoming). And the estimated probability of passing a proposal in the future, given that a proposal was passed this year, is shown in column 2 of Table 8 . Using these probabilities in equation (2), we estimate that the value of implementing a provision leads to a $2.7 \%$ increase in market value.

Therefore, in our data, adopting a governance provision increases shareholder value by between

\footnotetext{
${ }^{16}$ They estimate that the probability of implementation from proposals that obtain $50 \%$ to $60 \%$ of the vote in favor is $23.9 \%$. The probability that a proposal that failed will be implemented is $3.2 \%$. We obtain $20.7 \%$ as the difference between the two. See Table 1, Panel D and footnote 9 in Ertimur et al. (forthcoming).
} 
$2.7 \%$ and $2.8 \%$, depending on how we compute the estimate. This translates to an increase in market value for the average firm in the sample of around US\$600 million (average market value is US\$22,400 million in 1996 US\$) per proposal. This is an economically sizeable effect, especially when we consider that firms often drop several provisions in subsequent meetings. Dropping 2.5 provisions (one standard deviation of the G-index in the sample) translates into a predicted increase in market value of $7 \%$, implying that the economic consequences of poor governance arrangements are non-negligible.

\subsection{Long-run effects of governance}

In this final section, we evaluate the effect of passing a governance proposal on long-term firm outcomes. Evaluating these real effects is important for determining why the firm's market value increases following the improvement in shareholder rights and, in particular, following the removal of anti-takeover provisions. The increase in market value could simply reflect that the increased probability of a takeover may lead to a takeover premium. It could also result from an improvement in internal governance and managerial discipline. This would be the case if weak shareholder rights provided substantial protective power to standing managers (e.g., by insulating them from the takeover market), causing additional agency costs in the form of inefficient investments, reduced operational efficiency, and/or private benefits. ${ }^{17}$

All regressions in Table 9 use the empirical model in equation (7) to estimate the effect of passing a governance proposal on a number of long-term outcomes and, distinguish between the effect of anti-takeover and Other proposals. ${ }^{18}$ Since we are looking at effects up to 4 years after the vote, for proposals at the end of the sample we cannot estimate the long-run effects. This is particularly problematic for Other proposals because they are more frequent towards the end of the sample (only 47 observations fall close to the discontinuity prior to 2004), so one should interpret the long-run results for those with caution, especially at long durations. All regressions include firm-meeting fixed effects, and cluster standard errors by firm. In addition, our identification comes from the different response of a firm that passes a proposal by a small margin, relative to one that

\footnotetext{
${ }^{17}$ Previous studies found that the presence of weak shareholders' rights was correlated with higher levels of acquisitions and capital expenditures (as proxies for agency costs), lower valuation (as measured by Tobin's Q and book to market) and mixed results regarding accounting returns (return on equity and return on assets) (e.g., Gompers et al., 2003; Bebchuck et al., 2004; Core et al., 2006).

${ }^{18}$ Financial ratios and other dependent variables used in Table 9 typically have significant outliers. To avoid the effect of influential observations, for each column of Table 9 we restrict the sample to firm/votes that do not have any observation in the top or bottom $5 \%$ of the distribution of the dependent variable. The results are not sensitive to this particular outlier cut-off, but are sensitive to the inclusion of outliers.
} 
fails to pass a proposal by a small margin. This very demanding identification in terms of data requirements is bound to yield larger standard errors.

Columns 1 and 2 examine, respectively, whether the number and the value of acquisitions made by a firm change significantly in the years following the improvement in shareholder rights. Column 3 evaluates the effect on the growth of capital expenditures. Acquisitions may generate value, but they have also been associated with empire-building incentives and excess of free cash-flow problems that do not necessarily maximize shareholders' value. ${ }^{19}$ Some also argue that management entrenchment can lead to overinvestment or increases in corporate slack (Garvey and Hanka, 1999; Bertrand and Mullainathan, 2003; Giroud and Mueller, 2007). Therefore, one way in which improved governance can affect performance is through the reduction in unnecessary acquisitions, investments and capital-expenditures growth. We compute the number and value of firm acquisitions from the SDC database, which records all transactions of at least $5 \%$ of market value. The number of acquisitions is defined as the count of acquisitions made in a year, and the value is computed as the sum of all acquisition prices paid, divided by the average market capitalization on the first and last day of the year. ${ }^{20}$ We find that removing an anti-takeover provision reduces the number of acquisitions made in the years following the vote (column 1). The number falls by 0.03 the year after the vote, 0.17 two years later and 0.18 three years later (only this last coefficient is significant, though). We find a similar pattern for the value of these acquisitions (column 2). Column 3 shows that the growth of capital expenditures also seems to decline after a vote to eliminate G-index provisions. For other types of provisions, the effect is reversed, and capital expenditures actually increase a few years after the vote, but this is subject to the limitations of the data for those proposals at long durations mentioned earlier.

Finally, we examine the long-term performance effects of exogenous changes in governance. We use Compustat to construct the firm's Tobin's Q, book-to-market ratio and return on equity as measures of long-term valuation and performance. Column 4 of Table 9 shows that Tobin's Q increases significantly as a result of passing the governance proposals (both G-index and Other). Similarly, column 5 shows a significant reduction in the book-to-market ratio. ${ }^{21}$ Again, the effect

\footnotetext{
${ }^{19}$ There is evidence on acquisitions often being associated with negative abnormal returns for the bidder on announcement, as well as long-term negative performance (see, for example, Rau and Vermaelen 1998).

${ }^{20}$ We use the same measures as in Gompers et al. (2003).

${ }^{21}$ Tobin's Q is defined as the market value of assets divided by the book value of assets, where the market value of assets is computed as book value of assets (Compustat item: AT) plus the market value of common stock (Compustat item: mkvalt_f) minus the sum of the book value of common stock (Compustat item: CEQ) and balance sheet Deferred Taxes and Investment Tax Credit (Compustat item: TXDITC). All book values for fiscal year t are combined with the market value of common equity at the calendar end of year t. Book-to-market ratio is the ratio of book value of common equity (previous fiscal year) to market value of common equity (end of previous calendar
} 
is significant for both types of proposals. We also find evidence that return on equity (column 6) increases, but this is not significant for the G-index proposals. ${ }^{22}$

Overall, we find that, as a result of the removal of anti-takeover provisions, acquisitions and capital expenditures fall, firm valuation increases in the long-run, but there is little effect on earnings. While some of these effects are imprecisely estimated, taken as a whole, the above results indicate that acquisitions and capital expenditures fall as a result of the removal of anti-takeover provisions, and that firm valuation increases in the long run. This suggests that the abnormal returns that we identified in earlier sections as a result of governance improvements lead to actual changes in managers' actions. Further, if one is willing to interpret the marginal acquisitions and capital expenditures as value-destroying, and a way in which managers extract private benefits (e.g., though empire-building), then our evidence suggests that corporate governance proposals that remove antitakeover provisions increases shareholder value through the disciplining of management and the reduction in agency costs.

\section{Conclusion}

In this paper, we present novel evidence on the causal effect of corporate governance provisions on the firms' market value and long-term performance. We use a regression discontinuity model on the outcomes of votes on governance proposals in shareholder meetings. Firms that pass a proposal by a close margin are ex-ante similar to those that reject it by a close margin, so that passing a provision is "locally" exogenous, leading to a discrete increase in the probability of implementation. Therefore, this approach provides a causal estimate and overcomes the endogeneity problems that have affected the literature thus far. Our empirical strategy allows us to recover an estimate of the effect of governance even if, prior to the vote, the market had already incorporated the probability of passing the shareholder proposal into stock prices. This is because proposals that fell around the majority threshold were ex-ante the most uncertain, such that investors could not perfectly predict whether or not they would pass. It is for these proposals that we are able to observe a price reaction.

We show that, on average, the market reacts to the passage of a governance-related shareholder proposal with positive abnormal returns around $1.3 \%$ on the day of the vote. This reflects an

year). Book value of common equity is the sum of book common equity and deferred taxes.

${ }^{22}$ Return on Equity (ROE) is defined as net income (NI) divided by the book value of common stock (CEQ) plus balance sheet deferred taxes and Investment tax credit (TXDITC). 
increase in market value of between $2.7 \%$ and a $2.8 \%$ per implemented proposal. We identify some heterogeneity of this reaction, with the effect being more pronounced among firms with concentrated ownership, high pre-existing anti-takeover provisions and high R\&D expenditures. Firm behavior also changes with the new governance structure: Dropping anti-takeover provisions leads to lower investments and fewer acquisitions. Finally, the long-term performance of the firm, measured as Tobin's Q or book-to-market ratios, improves after two or three years when anti-takeover provisions are dropped; but we find modest results with respect to the return on equity.

As a whole, our results suggest that changing the internal corporate governance in targeted firms is rewarded by the market -with more pronounced effects for proposals to remove anti-takeover provisions-, and yields performance improvements in the long run. Our results also suggest that the channels behind these improvements include more conservative investment and acquisition policies.

Overall, our results provide causal evidence that the costs of the agency problem for modern corporations are non-negligible. A better understanding of the effect of governance provisions, and the magnitude of the agency problem is crucial to guiding the public debate on the adequacy of implementing and regulating corporate governance. It is also important to understand the potential role of shareholder activism in improving the governance of firms and creating value. Only causal estimates can be used to infer the impact of changing internal governance structures, such as the level of protection from takeover, compensation arrangements or board independence. This paper is an important step towards a better understanding of the effects of current governance arrangements.

\section{References}

Agrawal, Ashwini K. 2008. "Corporate Governance Objectives of Labor Union Shareholders: Evidence from Proxy Voting." New York University, Stern School of Business Working Paper FIN08-006.

Bebchuck, Lucian A., Alma Cohen, and Allen Ferrell. 2004. "What Matters in Corporate Governance?" Review of Financial Studies, 22(2): 783-827.

Becht, Marco, Patrick Bolton and Ailsa Röell. 2005. "Corporate Governance and Control." European Corporate Governance Institute Working Paper.

Bennedsen, Morten, Kasper M. Nielsen, Francisco Pérez-González, and Daniel Wolfenzon. 2007. "Inside the Family Firm: The Role of Families in Succession Decisions and Performance." Quarterly Journal of Economics, 122(2): 647-691.

Bertrand, Marianne, and Sendhil Mullainathan. 2001. "Are CEOs Rewarded for Luck? The Ones Without Principals Are." The Quarterly Journal of Economics, 116(3): 901-932. 
Bertrand, Marianne, and Sendhil Mullainathan. 2003. "Enjoying the Quiet Life? Corporate Governance and Managerial Preferences." Journal of Political Economy, 111(5): 1043-1075.

Berle, Adolf, and Gardiner Means. 1932. The Modern Corporation and Private Property. New York: Macmillian.

Brickley, James, Ronald C. Lease, and Clifford W. Smith Jr. 1988. "Ownership Structure and Voting on Antitakeover Amendments." Journal of Financial Economics, 20: 267-291.

Carhart, Mark M. 1997. "On Persistence in Mutual Fund Performance.” Journal of Finance, $52(1)$

Cellini, Stephanie R., Fernando Ferreira, and Jesse Rothstein. 2010. "The Value of School Facility Investments: Evidence from a Dynamic Regression Discontinuity Design." Quarterly Journal of Economics, 125(1): 215-261.

Comment, Robert G., and William Schwert. 1995. "Poison or Placebo? Evidence on the Deterrence and Wealth Effects of Modern Antitakeover Measures." Journal of Financial Economics, $39(1): 3-43$.

Core, John E., Wayne R. Guay, and Tjomme O. Rusticus. 2006. "Does Weak Governance Cause Weak Stock Returns? An Examination of Firm Operating Performance and Investors' Expectations." Journal of Finance, 61(2): 655-687.

Ertimur, Yonca, Fabrizio Ferri, and Stephen Stubben. forthcoming. "Board of Directors' Responsiveness to Shareholders: Evidence from Shareholder Proposals." Journal of Corporate Finance.

Fama, Eugene, and Michael Jensen. 1983. "Separation of Ownership and Control." Journal of Law and Economics, 26: 301-325.

Garvey, Gerald T., and Gordon Hanka. 1999. "Capital Structure and Corporate Control: The Effect of Antitakeover Statutes on Firm Leverage." Journal of Finance, 54(2): 519-546.

Gillan, Stuart L., and Laura T. Starks. 2000. "Corporate Governance Proposals and Shareholder Activism: The Role of Institutional Investors." Journal of Financial Economics, 57: 275-305.

Giroud, Xavier, and Holger M. Mueller. forthcoming. "Does Corporate Governance Matter in Competitive Industries?" Journal of Financial Economics.

Gompers, Paul A., Joy L. Ishii, and Andrew Metrick. 2003. "Corporate Governance and Equity Prices." Quarterly Journal of Economics, 118(1): 107-155.

Jensen, Michael C., and William H. Meckling. 1976. "Theory of the Firm: Managerial Behavior, Agency Costs, and Ownership Structure." Journal of Financial Economics, 3(4): 305-360.

Jensen, Michael C. 1986. "Agency Costs of Free Cash Flow, Corporate Finance, and Takeovers". 
The American Economic Review, 76(2): 323-329.

Kaplan, Steven N., and Luigi Zingales. 1997. "Do Investment-Cash Flow Sensitivities Provide Useful Measures of Financing Constraints." Quarterly Journal of Economics, 112(1): 169-215.

Karpoff, Jonathan, Paul Malatesta, and Ralph Walkling. 1996. "Corporate Governance and Shareholder Initiatives: Empirical Evidence," Journal of Financial Economics, 42: 365-395.

Lee, David. 2008. "Randomized Experiments from Nonrandom Selection in U.S. House Elections." Journal of Econometrics, 142(2): 675-97.

Lee, David, and Thomas Lemieux. forthcoming. "Regression Discontinuity Designs in Economics." Journal of Economic Literature.

Listokin, Yair. 2008. "Management Always Wins the Close Ones." American Law and Economics Review 2008 10(2):159-184.

McCrary, Justin. 2008. "Manipulation of the Running Variable in the Regression Discontinuity Design: A Density Test." Journal of Econometrics, 142(2): 698-714.

Pérez-González, Francisco. 2006. "Inherited Control and Firm Performance." American Economic Review, 96(5): 1559-1588.

Rau, Raghavendra, and Theo Vermaelen. 1998. "Glamour, Value and the Post-acquisition Performance of Acquiring Firms." Journal of Financial Economics, 49(2): 223-253.

Romano, Roberta. 2001. "Less Is More: Making Shareholder Activism a Valuable Mechanism of Corporate Governance," Yale Journal on Regulation, 18: 174-251.

Shleifer, Andrei, and Robert W. Vishny. 1997. "A Survey of Corporate Governance." Journal of Finance, 52(2).

Stein, Jeremy. 1988. "Takeover Threats and Managerial Myopia." Journal of Political Economy, 96: $61-80$.

Thomas, Randall and James F. Cotter, 2007. "Shareholder Proposals in the New Millennium: Shareholder Support, Board Response and Market Reaction." Journal of Corporate Finance, 13, 368-391. 


\section{Figures and Tables}

Figure 1: Market Reaction to Vote Outcomes

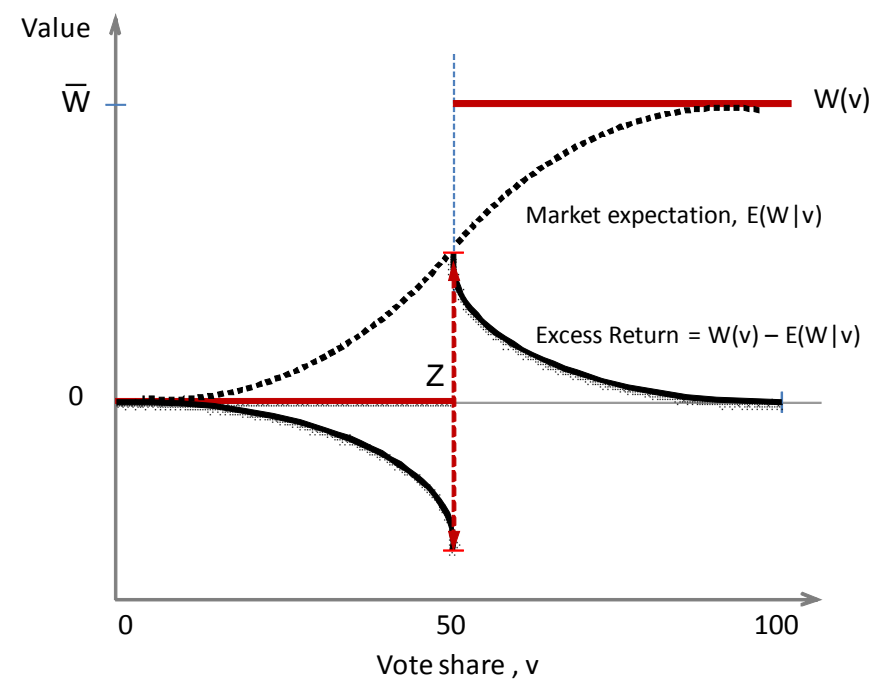

Figure 2: Excess Returns by Vote Share on the Day of the Vote

Notes: Graph shows average excess return by the vote share in favor of the proposal. Proposals are grouped into two percentage-point bins: Proposals that passed by between $0.001 \%$ and $2 \%$ are assigned to the 1 bin; those that failed by similar margins are assigned to the -1 bin. Excess returns are computed using the Fama-French and momentum factors from Carhart (1997).

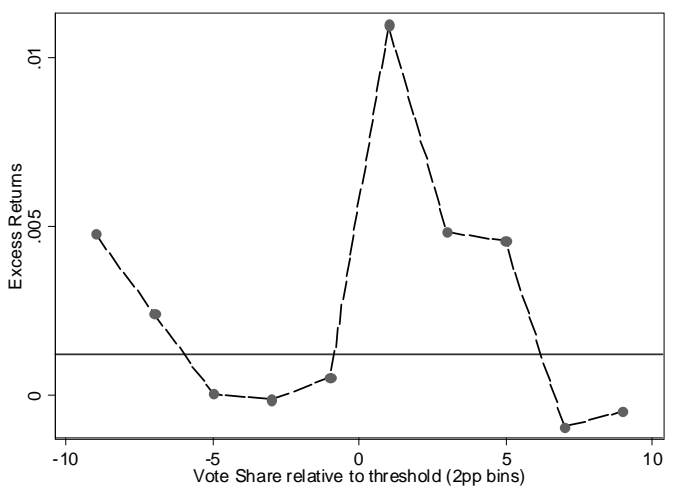


Figure 3: Distribution of Vote Shares for all Shareholder Governance Proposals

Notes: Sample includes all shareholders' governance proposals (N=3,984) from 1997 to 2007.

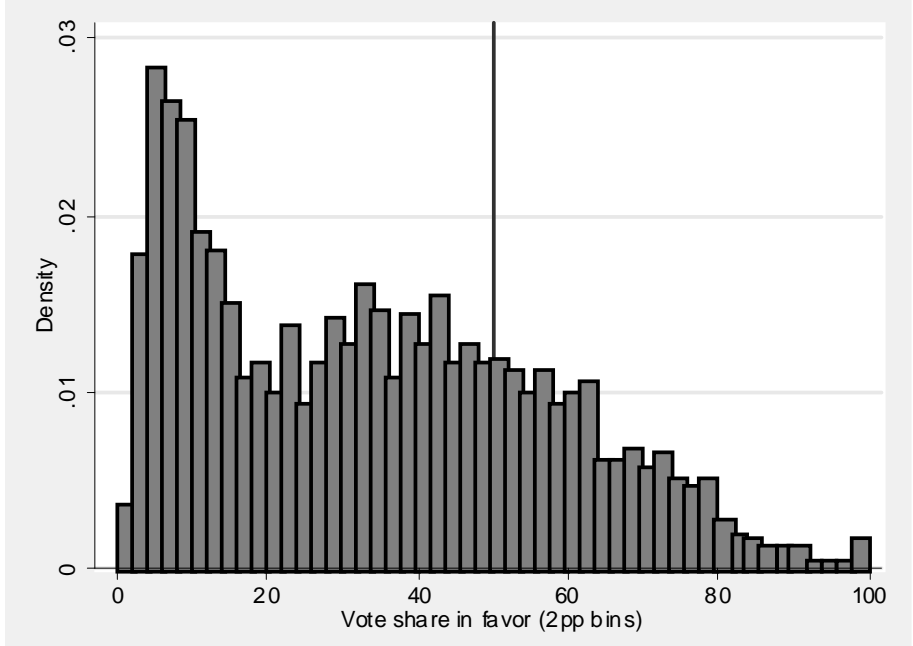

Figure 4: Distribution of Vote Shares for Shareholder Proposals to Remove Anti-Takeover Provisions (in G-index)

Notes: Sample includes all G-Index shareholder proposals $(\mathrm{N}=1,558)$ from 1997 to 2007

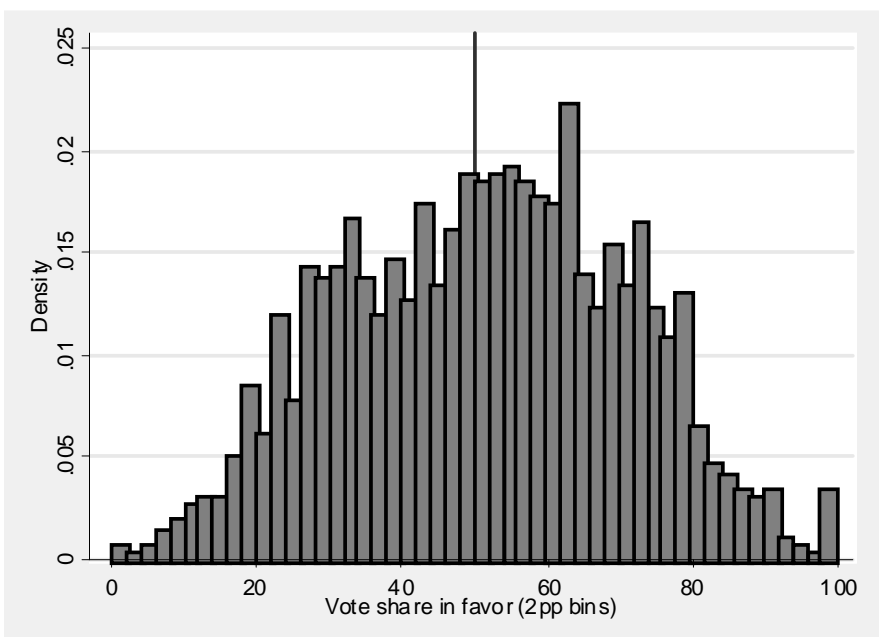


Figure 5: Distribution of Vote Shares for Other Shareholder Governance Proposals

Notes: Sample includes all 'Other' shareholder proposals $(\mathrm{N}=2,426)$ from 1997 to 2007

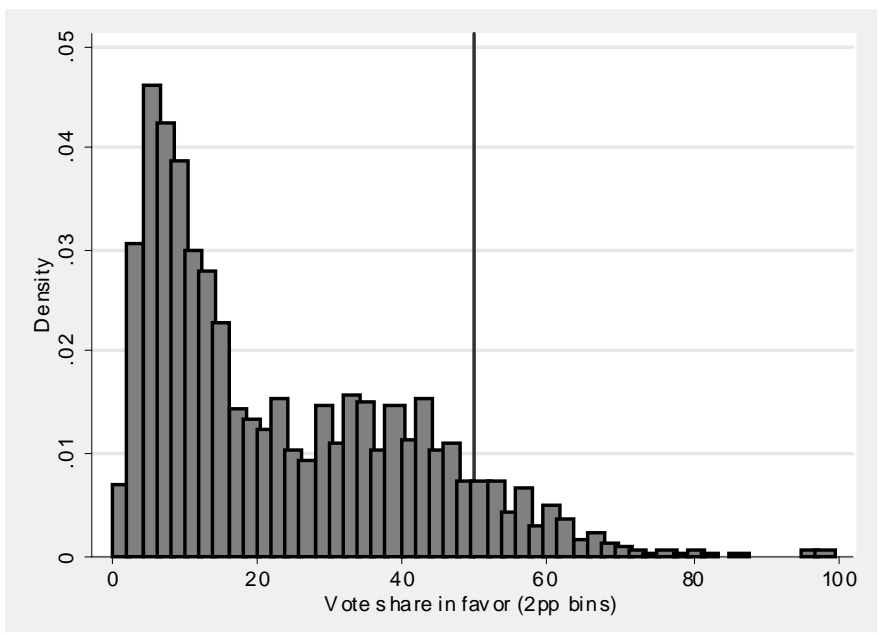

Figure 6: Day-by-Day Difference in Excess Returns, vote share in $[-5 ;+5]$ interval

Notes: The $\mathrm{Y}$ axis measures the difference in daily excess returns between proposals that pass by a close margin [up to to $+5 \%$ ] and proposals that are rejected by a close margin [up to $-5 \%$ ]. The $\mathrm{X}$ axis shows the different days before and after the vote (date 0 is the day when the vote is passed).

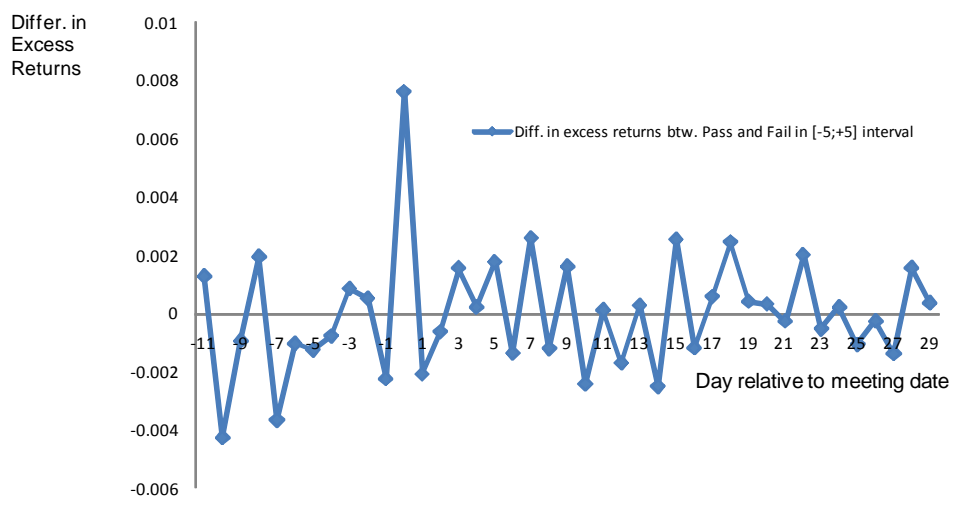


Figure 7: Distribution of Institutional Ownership and of Tobin's Q by Outcome of Shareholder Vote -G-index proposals

Notes: The distribution of the percentage of institutional ownership and Tobin's $Q$ is shown for three different brackets of vote outcomes $[0,45],[45,55],[55,100]$. The graph includes all the proposals in the sample that are included in the $\mathrm{G}$ index.

Institutional Ownership Concentration

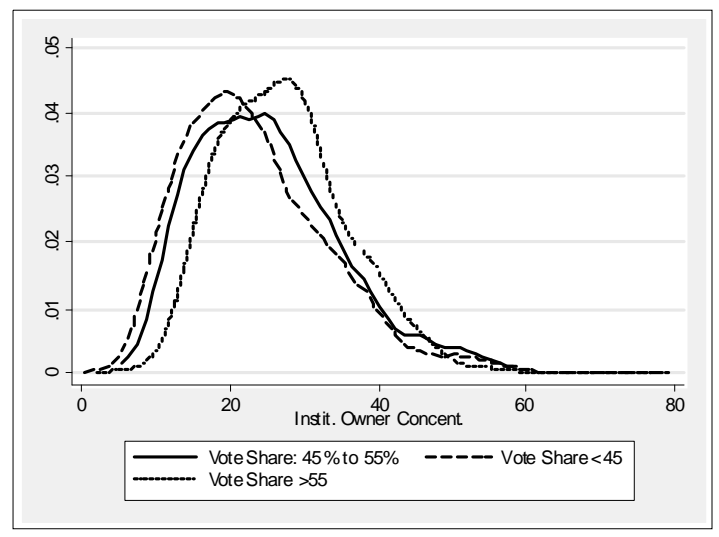

Tobin's Q

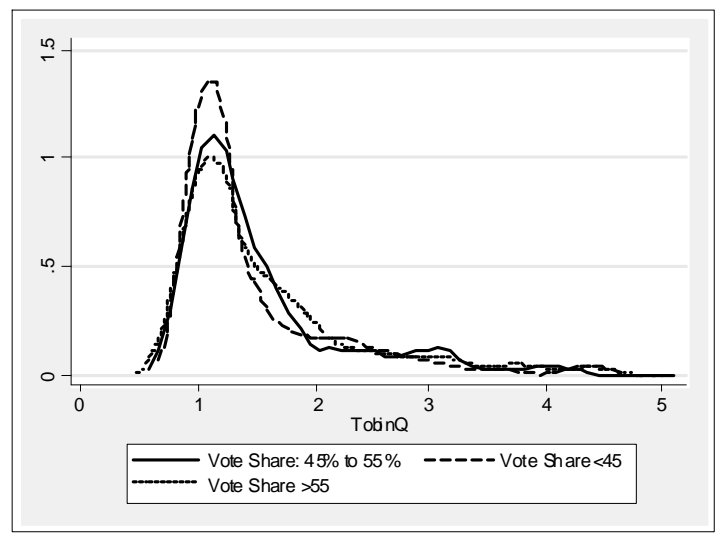

Figure 8: Distribution of Institutional Ownership and of Tobin's Q by Outcome of Shareholder Vote-Other proposals

Notes: The distribution of the percentage of institutional ownership and Tobin's $Q$ is shown for three different brackets of vote outcomes $[0,45],[45,55],[55,100]$. The graph includes all the proposals in the sample that are not included in the G index.

\section{Institutional Ownership Concentration}

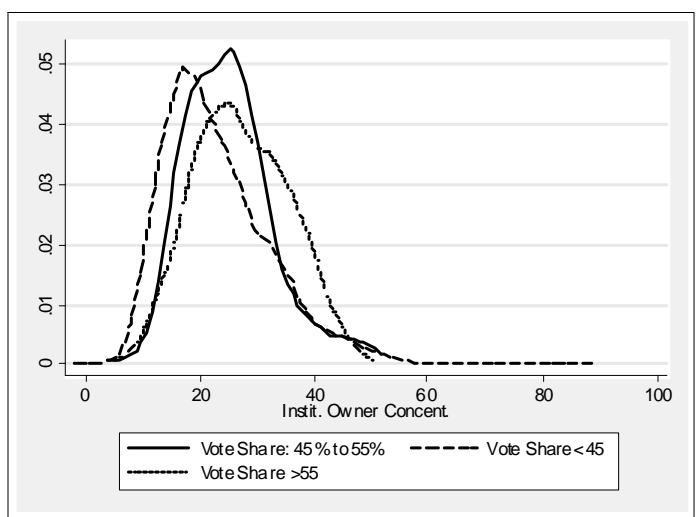

Tobin's Q

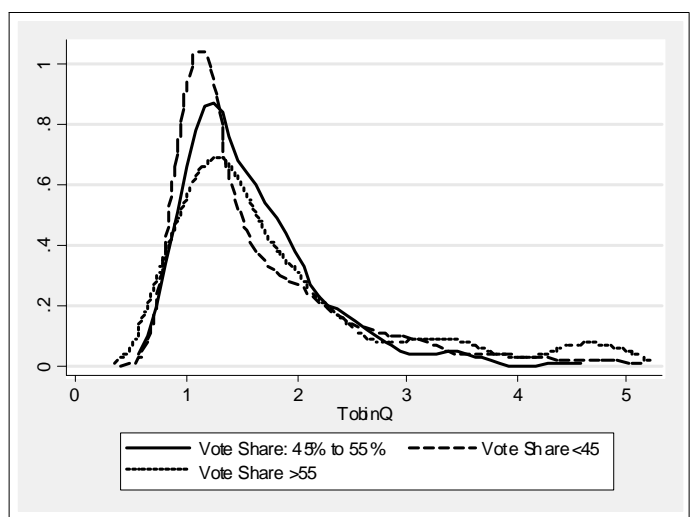


TABLE I

\section{Shareholder Governance Proposals}

Panel A displays the frequency, approval percentage and average support over time of governance proposals. Data are collected by Riskmetrics on all shareholder governance proposals from 1997 until 2007 for all S\&P 1,500 companies plus an additional 500 widelyheld firms. The threshold for approval is $50 \%$ for all but ten observations. We take into account the different threshold rules across proposals and firms for computing the percentage of approved proposals.

Panel A Shareholder Proposal Summary Statistics

\begin{tabular}{c|c|cc|cc}
\hline Year & $\begin{array}{c}\text { Shareholder } \\
\text { Proposals }\end{array}$ & $\begin{array}{c}\text { Approved } \\
\text { Proposals }\end{array}$ & $\begin{array}{c}\text { Percentage } \\
\text { Approved } \\
\text { Proposals }\end{array}$ & $\begin{array}{c}\text { Average } \\
\text { Vote } \\
\text { Outcome }\end{array}$ & $\begin{array}{c}\text { Std. Dev. } \\
\text { Vote } \\
\text { Outcome }\end{array}$ \\
\hline \hline 1997 & 292 & 29 & $9.90 \%$ & $23.13 \%$ & 17.46 \\
1998 & 272 & 37 & $13.66 \%$ & $26.29 \%$ & 19.11 \\
1999 & 310 & 58 & $18.70 \%$ & $28.60 \%$ & 21.84 \\
2000 & 272 & 70 & $25.00 \%$ & $30.95 \%$ & 23 \\
2001 & 277 & 67 & $24.00 \%$ & $30.03 \%$ & 22.21 \\
2002 & 297 & 100 & $33.60 \%$ & $36.61 \%$ & 23.38 \\
2003 & 479 & 166 & $34.60 \%$ & $37.50 \%$ & 23.27 \\
2004 & 451 & 126 & $27.00 \%$ & $33.12 \%$ & 25.05 \\
2005 & 417 & 124 & $29.70 \%$ & $37.17 \%$ & 23.99 \\
2006 & 450 & 143 & $31.70 \%$ & $40.87 \%$ & 22.66 \\
2007 & 467 & 120 & $25.70 \%$ & $37.31 \%$ & 21.97 \\
\hline \hline Total & $\mathbf{3 , 9 8 4}$ & $\mathbf{1 , 0 4 0}$ & $\mathbf{2 7 . 3 5 \%}$ & $\mathbf{3 6 . 1 6 \%}$ & \\
\hline \hline
\end{tabular}

Panel B Type of Governance Proposals (Broad Classification) -- Summary Statistics

\begin{tabular}{c|c|c|c}
\hline Proposal Type & \# Proposals & $\begin{array}{c}\text { Mean Vote in } \\
\text { Favor }\end{array}$ & $\begin{array}{c}\text { Percentage } \\
\text { Approved }\end{array}$ \\
\hline \hline Auditors & 68 & $22.70 \%$ & $4.40 \%$ \\
Board & 1,061 & $22 \%$ & $8.80 \%$ \\
Compensation & 520 & $23.00 \%$ & $4.20 \%$ \\
G-Index & 1,558 & $51 \%$ & $53 \%$ \\
Voting & 421 & $14 \%$ & $3.30 \%$ \\
Other & 356 & $33.90 \%$ & $21.00 \%$ \\
\hline \hline
\end{tabular}


TABLE II

\section{Descriptive Statistics}

Our sample of 3,984 proposals corresponds to 2,205 firm-year observations. Abnormal Returns are computed from CRSP. G-index is the number of anti-takeover provisions in place at the firm (Source: Riskmetrics). All accounting variables are obtained from Compustat: Total assets (AT), Market Value (mkvalt_f), Capital expenses (CAPX). Tobin's Q is defined as the market value of assets (AT+mkvalt_f-CEQ) divided by the book value of assets (AT), and balance sheet Deferred Taxes and Investment Tax Credit (TXDITC). Book-to-market is the ratio of book value of common equity (previous fiscal year) to market value of common equity (end of previous calendar year). Ownership by Top 5 Shareholders is the sum of institutional ownership for the top five shareholders in the last fiscal quarter before the meeting, and Institutional Shareholders that own at least 5\% is the number of shareholders that own at least 5\% of the firm's stock (Source: Thomson 13F Database).

Acquisitions Count is the number of acquisitions made in a year, Acquisitions Ratio is computed as the sum of all acquisition prices paid divided by the average market capitalization on the first and last day of the year (Source: SDC). All monetary values are in 1996 US\$. Note that the number of observations may change due to missing values in some of the variables.

\begin{tabular}{|c|c|c|c|c|c|}
\hline & $\mathbf{N}$ & Mean & Std. dev. & 10th Per. & 90th Per. \\
\hline Abnormal Return on meeting day & 2,377 & 0.001 & 0.023 & -0.020 & 0.023 \\
\hline G-index & 2,050 & 9.5 & 2.5 & 6 & 13 \\
\hline Total Assets(\$mil) & 2,369 & $43,794.83$ & 124,155 & 718.83 & $85,775.73$ \\
\hline Market Value (\$mil) & 2,011 & 22,431 & 44,477 & 485 & 62,404 \\
\hline EBITDA (\$mil) & 2,300 & $3,177.70$ & 6,320 & 52,29 & 8,223 \\
\hline Capital Expenses (\$mil) & 2,239 & 1,043 & 2,570 & 9.3 & 2,182 \\
\hline$R \& D /$ Assets & 2,369 & 0.018 & 0.045 & 0 & 0.065 \\
\hline Ownership by Top 5 Shareholders (\%) & 2,301 & 0.245 & 0.095 & 0.136 & 0.367 \\
\hline $\begin{array}{l}\text { Institutional Shareholders that own at } \\
\text { least } 5 \%\end{array}$ & 1,787 & 2.170 & 1.230 & 1 & 4 \\
\hline Tobin $Q$ & 1,805 & 1.588 & 0.69 & 1.01 & 2.67 \\
\hline Book to Market & 1,805 & 0.528 & 0.300 & 0.180 & 0.960 \\
\hline Return on Equity & 1,778 & 0.107 & 0.100 & -0.009 & 0.241 \\
\hline Growth of Capital Expenses & 1,908 & 0.059 & 0.300 & -0.31 & 0.45 \\
\hline Acquisitions Ratio & 1,960 & 0.016 & 0.030 & 0 & 0.064 \\
\hline Acquisitions Count & 1,991 & 0.53 & 0.80 & 0 & 2.00 \\
\hline
\end{tabular}




\section{TABLE III}

\section{Pre-differences in Firm Characteristics as a Function of the Vote Outcome}

Table 3 tests whether passing a vote on the meeting date is systematically related to firm characteristics prior to the meeting. Note that in Panel A t refers to days, while for the rest, t refers to years. Each row corresponds to a different dependent variable and each entry comes from a separate regression. Each entry in the table reports the coefficient on whether a proposal passed. Columns 1 and 2 (3 and 4) report the estimated effect of passing a vote on outcome variable levels (changes) the year before the annual meeting, $\mathrm{t}-1$ (between $\mathrm{t}-2$ and $\mathrm{t}-1$ ). Columns 1 and 3 present estimates without controlling for a polynomial in the vote share and, therefore, estimate the average effect of passing relative to not passing. Columns 2 and 4 include the polynomial in the vote share of order 4 on each side of the threshold such that it effectively estimates the effect at the discontinuity. All columns control for year fixed effects and standard errors (in parenthesis) are clustered at the firm level. Significance at the $10 \%, 5 \%$, and $1 \%$ levels are indicated by *, **, and *** respectively.

\begin{tabular}{|c|c|c|c|c|}
\hline & \multicolumn{2}{|c|}{ Before meeting (t-1) } & \multicolumn{2}{|c|}{ Change, from (t-2) to (t-1) } \\
\hline & (1) & (2) & (3) & (4) \\
\hline $\begin{array}{l}\text { A. } \\
\text { Abnormal Return one day before Meeting, } \\
\text { Car }(-1,-1)\end{array}$ & $\begin{array}{c}-0.00002 \\
(0.001)\end{array}$ & $\begin{array}{l}-0.004 \\
(0.003)\end{array}$ & $\begin{array}{c}0.001 \\
(0.003)\end{array}$ & $\begin{array}{l}-0.001 \\
(0.012)\end{array}$ \\
\hline $\begin{array}{l}\boldsymbol{B} . \\
\text { Tobin Q }\end{array}$ & $\begin{array}{l}-0.010 \\
(0.068)\end{array}$ & $\begin{array}{c}0.254 \\
(0.191)\end{array}$ & $\begin{array}{c}0.014 \\
(0.029)\end{array}$ & $\begin{array}{c}0.041 \\
(0.101)\end{array}$ \\
\hline Capital Expenses/Assets & $\begin{array}{l}-0.001 \\
(0.003)\end{array}$ & $\begin{array}{c}-3.88 \mathrm{E}-06 \\
(0.006)\end{array}$ & $\begin{array}{l}-0.002 \\
(0.001)\end{array}$ & $\begin{array}{c}0.003 \\
(0.003)\end{array}$ \\
\hline Return on Equity & $\begin{array}{c}1.65 \\
(1.63)\end{array}$ & $\begin{array}{l}-0.83 \\
(1.2)\end{array}$ & $\begin{array}{c}1.63 \\
(1.68)\end{array}$ & $\begin{array}{l}-0.69 \\
(1.21)\end{array}$ \\
\hline R\&D/Assets & $\begin{array}{c}0.003 \\
(0.002)\end{array}$ & $\begin{array}{l}-0.002 \\
(0.006)\end{array}$ & $\begin{array}{c}-0.00002 \\
(0.001)\end{array}$ & $\begin{array}{c}0.002 \\
(0.001)\end{array}$ \\
\hline C. & & & & \\
\hline Acquisitions Ratio & $\begin{array}{c}0.007 \\
(0.010) \\
\end{array}$ & $\begin{array}{c}-0.04 \\
(0.041) \\
\end{array}$ & $\begin{array}{r}-0.023 \\
(0.010) \\
\end{array}$ & $\begin{array}{l}-0.021 \\
(0.073) \\
\end{array}$ \\
\hline Acquisitions Count & $\begin{array}{l}-0.124^{*} \\
(0.070)\end{array}$ & $\begin{array}{l}0.193 \\
(0.21)\end{array}$ & $\begin{array}{l}-0.067 \\
(0.064)\end{array}$ & $\begin{array}{c}0.305 \\
(0.267)\end{array}$ \\
\hline $\begin{array}{l}\text { D. } \\
\text { Percentage Ownership by Top } 5 \\
\text { Shareholders }\end{array}$ & $\begin{array}{c}3.121^{* * *} \\
(0.616)\end{array}$ & $\begin{array}{l}-0.856 \\
(1.255)\end{array}$ & $\begin{array}{c}0.092 \\
(0.217)\end{array}$ & $\begin{array}{l}0.849 \\
(0.83)\end{array}$ \\
\hline $\begin{array}{l}\text { Institutional Shareholders that own at least } \\
5 \%\end{array}$ & $\begin{array}{c}0.319 * * * \\
(0.072)\end{array}$ & $\begin{array}{c}-0.24 \\
(0.199)\end{array}$ & $\begin{array}{c}0.018 \\
(0.049)\end{array}$ & $\begin{array}{c}0.29 \\
(0.204)\end{array}$ \\
\hline $\boldsymbol{E}$. & & & & \\
\hline G-index & $\begin{array}{c}1.242^{* * *} \\
(0.180)\end{array}$ & $\begin{array}{l}-0.514 \\
(0.391)\end{array}$ & $\begin{array}{l}-0.078 \\
(0.051)\end{array}$ & $\begin{array}{l}-0.101 \\
(0.173)\end{array}$ \\
\hline Polynomial in the vote share & no & yes & no & yes \\
\hline
\end{tabular}




\section{TABLE IV}

\section{Abnormal Returns around the Majority Threshold}

This table presents regressions of the abnormal returns on the day of the meeting $t=0$, on whether the proposal passed. Abnormal returns are computed using the Fama French and momentum factors from Carhart (1997). Column 1 estimates are based on the whole sample. Column 2 restricts the sample to observations with a vote share within ten points of the threshold, column 3 to five points and so forth. Column 6 introduces polynomial in the vote share of order 4, one on each side of the threshold, and uses the full sample. All columns control for year fixed effects; standard errors are clustered by firm. Significance at the $10 \%, 5 \%$, and $1 \%$ levels are indicated by $*, * *$, and $* * *$ respectively.

(1)

(2)

(3) (4)

(5)

(6)

\section{A. All Shareholders Proposals}

\begin{tabular}{rcccccc} 
& All votes & $-10 ;+10$ & $-5 ;+5$ & $-2 ;+2$ & $-1 ;+1$ & Full Model \\
\hline \hline Pass & 0.000922 & 0.00230 & $0.00761^{* * *}$ & $0.0105^{* *}$ & $0.0139 *$ & $0.0131^{* * *}$ \\
& $(0.000924)$ & $(0.00163)$ & $(0.00256)$ & $(0.00502)$ & $(0.00756)$ & $(0.00494)$ \\
Observations & 3904 & 909 & 450 & 183 & 91 & 3904 \\
R-squared & 0.000 & 0.002 & 0.024 & 0.032 & 0.039 & 0.014
\end{tabular}

\section{B. Anti-Takeover Proposals (In G-index)}

\begin{tabular}{rcccccc} 
& All votes & $-10 ;+10$ & $-5 ;+5$ & $-2 ;+2$ & $-1 ;+1$ & Full Model \\
\hline \hline Pass & $-9.51 \mathrm{e}-05$ & 0.00207 & $0.00940^{* * *}$ & $0.0162^{* *}$ & $0.0221^{* *}$ & $0.0169^{* *}$ \\
& $(0.00126)$ & $(0.00224)$ & $(0.00355)$ & $(0.00719)$ & $(0.0102)$ & $(0.00656)$ \\
Observations & 1531 & 523 & 264 & 114 & 61 & 1531 \\
R-squared & 0.000 & 0.002 & 0.027 & 0.053 & 0.070 & 0.033
\end{tabular}

\section{Shareholder Proposals Excluding Anti-Takeover Proposals}

\begin{tabular}{rcccccc} 
& All votes & $-10 ;+10$ & $-5 ;+5$ & $-2 ;+2$ & $-1 ;+1$ & Full Model \\
\hline \hline \multirow{2}{*}{ Pass } & 0.00202 & 0.00149 & $0.00399 *$ & 0.00112 & -0.00511 & 0.00529 \\
& $(0.00190)$ & $(0.00183)$ & $(0.00237)$ & $(0.00430)$ & $(0.00494)$ & $(0.00474)$ \\
Observations & 2373 & 386 & 186 & 69 & 30 & 2373 \\
R-squared & 0.001 & 0.002 & 0.014 & 0.001 & 0.035 & 0.016
\end{tabular}




\section{TABLE V}

\section{Abnormal Returns of Passing Governance Proposals}

This table presents the effect of passing a proposal on abnormal returns on the meeting date (t), on the day after $(t+1)$ and the cumulative effect from $t+2$ to $t+7$. The dependent variable in columns 1,3 and 4 is abnormal returns computed using the Fama French and momentum factors (FFM) from Carhart (1997); in columns 2 and 5, it is abnormal returns computed using the market model (MM). Column 3 allows for 6 different dummy variables to capture the number of proposals (1 to 6) that passed at the meeting. Columns 4 and 5 allow for a separate effect of anti-takeover proposals (labeled as G-index proposals) and 'Other' governance proposals. The specification in all columns is given by equation 8 . All columns control for year fixed effects, firm-meeting fixed effects and distance to the election effects; standard errors in parentheses are clustered by firm. Significance at the $10 \%, 5 \%$, and $1 \%$ levels are indicated by $*$, **, and *** respectively.

\begin{tabular}{|c|c|c|c|c|c|c|}
\hline & \multicolumn{3}{|c|}{ Abnormal Returns } & \multicolumn{3}{|c|}{ Abnormal Returns } \\
\hline & $\begin{array}{c}\text { FFM } \\
(1) \\
\end{array}$ & $\begin{array}{c}\mathbf{M M} \\
(2) \\
\end{array}$ & $\begin{array}{c}\text { FFM } \\
(3) \\
\end{array}$ & & $\begin{array}{c}\text { FFM } \\
(4) \\
\end{array}$ & $\begin{array}{c}\text { MM } \\
(5) \\
\end{array}$ \\
\hline Day of vote, $t$ & $\begin{array}{c}0.013 * * \\
(0.005)\end{array}$ & $\begin{array}{c}0.014 * * * \\
(0.005)\end{array}$ & & G-index & $\begin{array}{c}0.014^{* *} \\
(0.007)\end{array}$ & $\begin{array}{c}0.013 * \\
(0.007)\end{array}$ \\
\hline One day later, $\mathrm{t}+1$ & $\begin{array}{c}0.002 \\
(0.004)\end{array}$ & $\begin{array}{c}0.004 \\
(0.004)\end{array}$ & $\begin{array}{c}0.002 \\
(0.004)\end{array}$ & G-index & $\begin{array}{c}-0.001 \\
(0.006)\end{array}$ & $\begin{array}{c}0.000 \\
(0.006)\end{array}$ \\
\hline Days $\mathrm{t}+2$ to $\mathrm{t}+7$ & $\begin{array}{c}0.010 \\
(0.006) \\
\end{array}$ & $\begin{array}{c}0.007 \\
(0.007) \\
\end{array}$ & $\begin{array}{c}0.010 \\
(0.006) \\
\end{array}$ & G-index & $\begin{array}{c}0.011 \\
(0.009) \\
\end{array}$ & $\begin{array}{r}0.010 \\
(0.009) \\
\end{array}$ \\
\hline \multicolumn{7}{|l|}{ Day of vote, $\mathrm{t}$} \\
\hline 1 vote passed & & & $\begin{array}{c}0.013 * * \\
(0.005)\end{array}$ & & & \\
\hline 2 votes passed & & & $\begin{array}{c}0.022 * * \\
(0.010)\end{array}$ & & & \\
\hline 3 votes passed & & & $\begin{array}{c}0.046 * * * \\
(0.017)\end{array}$ & & & \\
\hline 4 votes passed & & & $\begin{array}{c}0.046 * * \\
(0.022)\end{array}$ & & & \\
\hline 5 votes passed & & & $\begin{array}{c}0.071 * * \\
(0.030)\end{array}$ & & & \\
\hline 6 votes passed & & & $\begin{array}{c}0.115^{* * *} \\
(0.031)\end{array}$ & & & \\
\hline Day of vote, $t$ & & & & Other & $\begin{array}{c}0.009 \\
(0.006)\end{array}$ & $\begin{array}{c}0.012 * * \\
(0.006)\end{array}$ \\
\hline One day later, $\mathrm{t}+1$ & & & & Other & $\begin{array}{c}0.007 \\
(0.005)\end{array}$ & $\begin{array}{l}0.011 * \\
(0.005)\end{array}$ \\
\hline Days $t+2$ to $t+7$ & & & & Other & $\begin{array}{c}0.004 \\
(0.008) \\
\end{array}$ & $\begin{array}{c}-0.000 \\
(0.010) \\
\end{array}$ \\
\hline Observations & 11884 & 11884 & 11884 & & 11884 & 11884 \\
\hline R-squared & 0.002 & 0.005 & 0.002 & & 0.005 & 0.007 \\
\hline Number of firm-meeting & 2377 & 2377 & 2377 & & 2377 & 2377 \\
\hline
\end{tabular}




\section{TABLE VI}

\section{Abnormal Returns and Firm Heterogeneity}

This table presents the effect of passing a proposal on abnormal returns on the meeting date (t), on the day after $(t+1)$ and the cumulative effect from $t+2$ to $t+7$ for different subsamples of firms. The dependent variables in all Columns are abnormal returns computed using the Fama French and momentum factors from Carhart (1997) and the cumulative effect from $\mathrm{t}+2$ to $\mathrm{t}+7$ for different firm subsamples. Columns 1 and 4 include firms with above-median ownership concentration (percentage controlled by the top five institutional owners); Columns 2 and 5 include firms with ten or more anti-takeovers provision (above-median G-index) before the meeting; Columns 3 and 6 include firms with above median R\&D/Assets ratio. Columns 4, 5 and 6 allow for a separate effect of anti-takeover proposals (labeled as G-index proposals) and Other governance proposals. The specification in all columns is given by equation 8 . All columns control for year fixed effects, firm-meeting fixed effects and distance to the election effects; standard errors in parentheses are clustered by firm.

Significance at the $10 \%, 5 \%$, and $1 \%$ levels are indicated by *, **, and *** respectively.

\begin{tabular}{|c|c|c|c|c|c|c|c|}
\hline & $\begin{array}{c}\text { All Sha } \\
\text { High } \\
\text { Ownership } \\
\text { Concentration }\end{array}$ & $\begin{array}{l}\text { reholders Propo } \\
\text { High G-index }\end{array}$ & High R\&D & & $\begin{array}{c}\text { G-i } \\
\text { High } \\
\text { Ownership } \\
\text { Concentration }\end{array}$ & ndex vs. Other & High R\&D \\
\hline & $(1)$ & $(2)$ & (3) & & $(4)$ & $(5)$ & (6) \\
\hline Day of vote, $t$ & $\begin{array}{c}0.020^{* * *} \\
(0.007)\end{array}$ & $\begin{array}{l}0.017^{* *} \\
(0.007)\end{array}$ & $\begin{array}{l}0.016^{* *} \\
(0.008)\end{array}$ & G-index & $\begin{array}{l}0.021^{* *} \\
(0.010)\end{array}$ & $\begin{array}{l}0.019 * * \\
(0.009)\end{array}$ & $\begin{array}{l}0.018^{*} \\
(0.010)\end{array}$ \\
\hline One day later, $\mathrm{t}+1$ & $\begin{array}{c}0.008 \\
(0.005)\end{array}$ & $\begin{array}{c}0.003 \\
(0.006)\end{array}$ & $\begin{array}{c}0.006 \\
(0.008)\end{array}$ & G-index & $\begin{array}{c}0.002 \\
(0.008)\end{array}$ & $\begin{array}{c}0.001 \\
(0.007)\end{array}$ & $\begin{array}{c}0.005 \\
(0.010)\end{array}$ \\
\hline Days $t+2$ to $t+7$ & $\begin{array}{l}0.015^{* *} \\
(0.008) \\
\end{array}$ & $\begin{array}{l}0.020^{* *} \\
(0.009) \\
\end{array}$ & $\begin{array}{c}0.002 \\
(0.011) \\
\end{array}$ & G-index & $\begin{array}{l}0.019^{*} \\
(0.010) \\
\end{array}$ & $\begin{array}{c}0.023^{* *} \\
(0.011) \\
\end{array}$ & $\begin{array}{c}0.005 \\
(0.013) \\
\end{array}$ \\
\hline Day of vote, $t$ & & & & Other & $\begin{array}{c}0.009 \\
(0.008)\end{array}$ & $\begin{array}{c}0.010 \\
(0.010)\end{array}$ & $\begin{array}{c}0.008 \\
(0.009)\end{array}$ \\
\hline One day later, $\mathrm{t}+1$ & & & & Other & $\begin{array}{l}0.012^{*} \\
(0.007)\end{array}$ & $\begin{array}{c}0.008 \\
(0.011)\end{array}$ & $\begin{array}{c}0.012 \\
(0.008)\end{array}$ \\
\hline Days $t+2$ to $t+7$ & & & & Other & $\begin{array}{c}0.004 \\
(0.011)\end{array}$ & $\begin{array}{c}0.008 \\
(0.015)\end{array}$ & $\begin{array}{l}-0.006 \\
(0.012)\end{array}$ \\
\hline 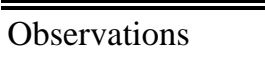 & 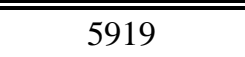 & $\overline{5704}$ & 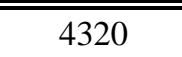 & & 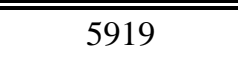 & 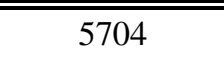 & 24320 \\
\hline R-squared & 0.007 & 0.008 & 0.007 & & 0.016 & 0.012 & 0.017 \\
\hline $\begin{array}{l}\text { Number of firm- } \\
\text { meeting }\end{array}$ & 1184 & 1141 & 864 & & 1184 & 1141 & 864 \\
\hline
\end{tabular}




\section{TABLE VII}

\section{Effect of Passing a Governance Proposal on the G-index}

Column 1 shows the effect of passing a governance proposal on the number of antitakeover provisions in place at the firm (the G-index). The index is provided by Riskmetrics every two years. The first coefficient (Year of vote, $t$ ) is the effect of passing a proposal on the G-index for the first year available in Riskmetrics that is at least six months after the meeting; the second coefficient is the effect two years after that, etc. Column 2 allows for 6 different dummy variables to capture the number of proposals (1 to 6 ) that passed at the meeting. The specification in all columns is given by equation 8 . All columns control for year fixed effects, firmmeeting fixed effects and distance to the election effects; standard errors are clustered by firm. Significance at the $10 \%, 5 \%$, and $1 \%$ levels are indicated by *, **, and ${ }^{* * *}$ respectively.

\section{G-index}

Year of vote, $\mathrm{t}$

Two years later, $\mathrm{t}+2$

Four years later, $\mathrm{t}+4$

Six years later, $\mathrm{t}+6$

Year of vote, $t$
(1)

(2)

$-0.313^{* * *}$

$-0.329 * *$

$-0.329 * *$

$-0.503^{* *}$

(0.229)

$-0.508$

(0.389)

$-0.511$

\begin{tabular}{lcc} 
1 vote passed & $-0.336^{* * *}$ \\
& & $(0.108)$ \\
& 2 votes passed & $-0.581^{* * *}$ \\
& & $(0.217)$ \\
& & $-0.744^{* *}$ \\
& & $(0.318)$ \\
& & $-1.828^{* * *}$ \\
& 4 votes passed & $(0.589)$ \\
& & $-2.393^{* * *}$ \\
& & $(0.562)$ \\
\hline \hline & & \\
Observations & & 9386 \\
R-squared & & 0.045 \\
Number of firm-meeting & 9386 & 2198 \\
\hline \hline
\end{tabular}

$-0.336^{* * *}$$$
\text { (0.108) }
$$

$-1.828 * * *$

(0.589)

$-2.393^{* * *}$

$(0.562)$ 


\section{TABLE VIII}

\section{Effect of Passing a Governance Proposals on Passing Future Proposals}

The dependent variable is the total number of proposals passed in a given year in column 1 , the total number of G-index proposals passed in column 2 and the total number of Other proposals passed in column 3. It is equal to zero if a there were no proposals or no proposal was passed. All columns provide separately the effect of G-index and other kinds of proposals on the dependent variable. This is estimated using equation (8), and dropping the observation for $\mathrm{t}=0$ the year of the meeting (where the effect is by definition 1). All columns include a polynomial in the vote share and can be interpreted as the effect of passing a proposal on the number of proposals passed in the future, at the discontinuity. All columns control for year fixed effects, firm-meeting fixed effects and distance to the election effects; standard errors are clustered by firm. Significance at the $10 \%, 5 \%$, and $1 \%$ levels are indicated by *, **, and *** respectively.

Number of Proposals Passed

All Proposals G-index Proposals Other Proposals

\begin{tabular}{|c|c|c|c|c|}
\hline & & (1) & (2) & (3) \\
\hline \multirow[t]{2}{*}{ One Year later, $\mathrm{t+1}$} & G-index & $0.325^{* * * *}$ & $0.326 * * *$ & -0.001 \\
\hline & & $(0.111)$ & $(0.109)$ & $(0.021)$ \\
\hline \multirow[t]{2}{*}{ Two years later, $\mathrm{t}+2$} & G-index & $0.119 * *$ & $0.096 * *$ & 0.023 \\
\hline & & $(0.059)$ & $(0.042)$ & $(0.038)$ \\
\hline \multirow[t]{2}{*}{ Three years later, $\mathrm{t}+3$} & G-index & $0.138 * * *$ & $0.103^{* *}$ & 0.036 \\
\hline & & $(0.048)$ & $(0.043)$ & $(0.025)$ \\
\hline \multirow[t]{2}{*}{ Four years later, $t+4$} & G-index & 0.051 & 0.059 & -0.008 \\
\hline & & $(0.045)$ & $(0.043)$ & $(0.016)$ \\
\hline \multirow[t]{2}{*}{ Five years later, $\mathrm{t}+5$} & G-index & 0.070 & $0.079 *$ & -0.008 \\
\hline & & $(0.045)$ & $(0.043)$ & $(0.016)$ \\
\hline \multirow[t]{2}{*}{ Six years later, $\mathrm{t}+6$} & G-index & 0.054 & 0.062 & -0.008 \\
\hline & & $(0.049)$ & $(0.047)$ & $(0.016)$ \\
\hline \multirow[t]{2}{*}{ One Year later, t+1 } & Other & -0.052 & -0.003 & -0.049 \\
\hline & & $(0.139)$ & $(0.110)$ & $(0.077)$ \\
\hline \multirow[t]{2}{*}{ Two years later, $\mathrm{t}+2$} & Other & $-0.123 *$ & -0.030 & $-0.093^{*}$ \\
\hline & & $(0.074)$ & $(0.040)$ & (0.049) \\
\hline \multirow[t]{2}{*}{ Three years later, $t+3$} & Other & -0.029 & -0.003 & -0.026 \\
\hline & & $(0.078)$ & $(0.040)$ & $(0.055)$ \\
\hline \multirow[t]{2}{*}{ Four years later, t+4 } & Other & -0.069 & 0.002 & -0.070 \\
\hline & & $(0.070)$ & $(0.040)$ & $(0.044)$ \\
\hline \multirow[t]{2}{*}{ Five years later, $\mathrm{t}+5$} & Other & -0.071 & -0.001 & -0.070 \\
\hline & & $(0.070)$ & $(0.039)$ & $(0.044)$ \\
\hline \multirow[t]{2}{*}{ Six years later, t+6 } & Other & -0.057 & 0.013 & -0.070 \\
\hline & & $(0.071)$ & $(0.042)$ & $(0.044)$ \\
\hline \multicolumn{2}{|c|}{ Polynomial in the vote share } & yes & yes & yes \\
\hline \multicolumn{2}{|l|}{ Observations } & 19016 & 19016 & 19016 \\
\hline \multicolumn{2}{|l|}{ R-squared } & 0.058 & 0.047 & 0.040 \\
\hline \multicolumn{2}{|c|}{ Number of firm-meeting } & 2377 & 2377 & 2377 \\
\hline
\end{tabular}


TABLE IX

\section{Long-run Effects of Governance Proposals}

This table presents the effect of passing a governance proposal on firm long-term outcomes. The specification in all columns is given by equation 8. All columns allow for a separate effect of anti-takeover proposals (labeled as G-index proposals) and Other governance proposals. The dependent variables are: the number of acquisitions in column 1; the acquisitions ratio--sum of all acquisition prices paid divided by the average market capitalization on the first and last day of the year-- in column 2; the growth rate of capital expenditures in column 3; Tobin Q in column 4 (defined as the market value of assets divided by the book value of assets, where the market value of assets is computed as the book value of assets plus the market value of common stock minus the book value of common stock and deferred taxes (Kaplan and Zingales (1997)); book-to-market value of the firm in column 5; returns on equity in 6. See notes to Table 2 for further sources and definitions. Standard errors in parentheses are clustered by firm. Significance at the 10\%, 5\%, and $1 \%$ levels are

indicated by *** and *** respectivelv

\begin{tabular}{|c|c|c|c|c|c|c|c|}
\hline & & $\begin{array}{c}\text { Acquisitions } \\
\text { Count } \\
(1) \\
\end{array}$ & $\begin{array}{l}\text { Acquisitions } \\
\text { Ratio } \\
(2) \\
\end{array}$ & $\begin{array}{c}\text { Capex } \\
\text { Growth } \\
(3) \\
\end{array}$ & $\begin{array}{c}\text { TobinQ } \\
(4) \\
\end{array}$ & $\begin{array}{c}\text { Book-to- } \\
\text { Market } \\
(5) \\
\end{array}$ & $\begin{array}{c}\text { ROE } \\
(6) \\
\end{array}$ \\
\hline Year of Meeting, $t$ & G-index & $\begin{array}{c}-0.00141 \\
(0.120)\end{array}$ & $\begin{array}{l}-0.00143 \\
(0.00624)\end{array}$ & $\begin{array}{l}-0.0797 \\
(0.0541)\end{array}$ & $\begin{array}{l}-0.0127 \\
(0.0470)\end{array}$ & $\begin{array}{l}-0.0172 \\
(0.0270)\end{array}$ & $\begin{array}{l}0.00892 \\
(0.0181)\end{array}$ \\
\hline One Year later, $t+1$ & G-index & $\begin{array}{l}-0.0309 \\
(0.102)\end{array}$ & $\begin{array}{c}0.00234 \\
(0.00619)\end{array}$ & $\begin{array}{l}-0.117 * * \\
(0.0577)\end{array}$ & $\begin{array}{c}0.0596 \\
(0.0612)\end{array}$ & $\begin{array}{l}-0.0255 \\
(0.0337)\end{array}$ & $\begin{array}{c}0.0268 \\
(0.0183)\end{array}$ \\
\hline Two years later, $\mathrm{t}+2$ & G-index & $\begin{array}{l}-0.166 \\
(0.109)\end{array}$ & $\begin{array}{r}-0.000422 \\
(0.00779)\end{array}$ & $\begin{array}{l}-0.0411 \\
(0.0664)\end{array}$ & $\begin{array}{c}0.0978 \\
(0.0758)\end{array}$ & $\begin{array}{l}-0.0648 * \\
(0.0342)\end{array}$ & $\begin{array}{c}0.0189 \\
(0.0177)\end{array}$ \\
\hline Three years later, $\mathrm{t}+3$ & G-index & $\begin{array}{c}-0.181 * \\
(0.108)\end{array}$ & $\begin{array}{c}-0.0124 * * * \\
(0.00468)\end{array}$ & $\begin{array}{l}-0.00389 \\
(0.0671)\end{array}$ & $\begin{array}{l}0.222 * * \\
(0.0903)\end{array}$ & $\begin{array}{c}-0.0970 * * * \\
(0.0362)\end{array}$ & $\begin{array}{c}0.0179 \\
(0.0181)\end{array}$ \\
\hline Four years later, $\mathrm{t}+4$ & G-index & $\begin{array}{r}0.166 \\
(0.134) \\
\end{array}$ & $\begin{array}{c}0.00738 \\
(0.00870) \\
\end{array}$ & $\begin{array}{l}-0.0923 \\
(0.0648) \\
\end{array}$ & $\begin{array}{l}0.199 * * \\
(0.0988)\end{array}$ & $\begin{array}{c}-0.0941^{* *} \\
(0.0419)\end{array}$ & $\begin{array}{l}0.00336 \\
(0.0198) \\
\end{array}$ \\
\hline Year of Meeting, $t$ & Other & $\begin{array}{l}0.0385 \\
(0.122)\end{array}$ & $\begin{array}{l}-0.00433 \\
(0.00514)\end{array}$ & $\begin{array}{c}0.114 \\
(0.0832)\end{array}$ & $\begin{array}{l}0.156^{* * *} \\
(0.0459)\end{array}$ & $\begin{array}{c}-0.0607 * * \\
(0.0254)\end{array}$ & $\begin{array}{c}0.0131 \\
(0.0165)\end{array}$ \\
\hline One Year later, $\mathrm{t}+1$ & Other & $\begin{array}{c}0.135 \\
(0.132)\end{array}$ & $\begin{array}{l}-0.00845 \\
(0.00705)\end{array}$ & $\begin{array}{l}0.0161 \\
(0.106)\end{array}$ & $\begin{array}{l}0.229 * * \\
(0.0995)\end{array}$ & $\begin{array}{l}-0.107^{* *} \\
(0.0436)\end{array}$ & $\begin{array}{c}0.0435 * * * \\
(0.0158)\end{array}$ \\
\hline Two years later, $\mathrm{t}+2$ & Other & $\begin{array}{c}0.316 \\
(0.223)\end{array}$ & $\begin{array}{l}0.00972 \\
(0.0111)\end{array}$ & $\begin{array}{c}0.157 \\
(0.103)\end{array}$ & $\begin{array}{c}0.00230 \\
(0.197)\end{array}$ & $\begin{array}{l}0.00972 \\
(0.0724)\end{array}$ & $\begin{array}{c}0.0829 * * \\
(0.0399)\end{array}$ \\
\hline Three years later, $\mathrm{t}+3$ & Other & $\begin{array}{c}0.249 \\
(0.214)\end{array}$ & $\begin{array}{l}-0.00464 \\
(0.00843)\end{array}$ & $\begin{array}{c}0.463^{* * *} \\
(0.144)\end{array}$ & $\begin{array}{l}-0.0232 \\
(0.164)\end{array}$ & $\begin{array}{l}-0.0266 \\
(0.0447)\end{array}$ & $\begin{array}{c}0.112 * * * \\
(0.0426)\end{array}$ \\
\hline Four years later, $\mathrm{t}+4$ & Other & $\begin{array}{c}0.500 * * \\
(0.253)\end{array}$ & $\begin{array}{c}0.0421 \\
(0.0312) \\
\end{array}$ & $\begin{array}{c}0.664 * * \\
(0.257)\end{array}$ & $\begin{array}{r}-0.102 \\
(0.307) \\
\end{array}$ & $\begin{array}{r}0.0444 \\
(0.101) \\
\end{array}$ & $\begin{array}{c}0.121^{* * *} \\
(0.0462)\end{array}$ \\
\hline $\begin{array}{l}\text { Observations } \\
\text { R-squared } \\
\text { Number of firm-meeting }\end{array}$ & & $\begin{array}{l}11384 \\
0.022 \\
1797\end{array}$ & $\begin{array}{c}9105 \\
0.008 \\
1555\end{array}$ & $\begin{array}{l}6501 \\
0.027 \\
1524\end{array}$ & $\begin{array}{c}9062 \\
0.030 \\
1823\end{array}$ & $\begin{array}{l}9120 \\
0.024 \\
1817\end{array}$ & $\begin{array}{l}8166 \\
0.028 \\
1573\end{array}$ \\
\hline
\end{tabular}


Appendix A - Description of All Shareholders Proposals (Riskmetrics 1997-2007)

Discont

\begin{tabular}{|c|c|c|c|c|c|c|}
\hline Type & Description Proposal & Obs & Mean Vote For & $\#-5,+5$ & $\#-10,10$ & Freq. \\
\hline \multirow[t]{3}{*}{$\overline{\text { Audit }}$} & "Limit consulting by auditors & 59 & 20.1 & 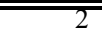 & $\overline{5}$ & \\
\hline & Shareholder approval of auditors & 7 & 48.0 & 2 & 3 & \\
\hline & Rotate Auditor & 2 & 5.3 & 0 & 0 & 68 \\
\hline \multirow[t]{14}{*}{$\overline{\text { Board }}$} & Separate chairman/CEO & 224 & 28.2 & 15 & 33 & \\
\hline & Majority independent directors & 89 & 26.1 & 5 & 9 & \\
\hline & Commit to/report on board diversity & 60 & 16.7 & 0 & 1 & \\
\hline & Limit director tenure & 54 & 6.3 & 0 & 1 & \\
\hline & Independent nominating committee & 24 & 25.7 & 2 & 2 & \\
\hline & Increase key committee independence & 15 & 19.0 & 0 & 0 & \\
\hline & Allow union/employee reps on the board & 11 & 7.7 & 0 & 0 & \\
\hline & Increase compensation committee independence & 10 & 35.1 & 3 & 4 & \\
\hline & Minimum director stock ownership & 9 & 7.6 & 0 & 0 & \\
\hline & Independent compensation committee & 7 & 18.8 & 0 & 0 & \\
\hline & Lead director & 6 & 24.4 & 0 & 1 & \\
\hline & Shareholder advisory committee & 4 & 10.2 & 0 & 0 & \\
\hline & Increase audit committee Independence & 4 & 19.5 & 0 & 0 & \\
\hline & Create nominating committee & 3 & 24.7 & 0 & 0 & 520 \\
\hline \multirow[t]{18}{*}{ Compensation } & Link pay to performance/Recoup Bonuses & 371 & 16.0 & 12 & 21 & \\
\hline & Award performance-based stock options & 114 & 23.6 & 6 & 17 & \\
\hline & Expense stock options & 112 & 50.1 & 39 & 68 & \\
\hline & Link executive pay to social criteria & 109 & 8.2 & 0 & 0 & \\
\hline & Disclose executive compensation & 59 & 11.5 & 1 & 3 & \\
\hline & Advisory vote on compensation & 53 & 41.5 & 14 & 33 & \\
\hline & Misc Compensation & 42 & 25.6 & 3 & 10 & \\
\hline & Cap executive pay & 35 & 8.0 & 0 & 0 & \\
\hline & Add performance criteria to equity-based awards & 31 & 34.4 & 6 & 12 & \\
\hline & Restrict director compensation & 29 & 9.6 & 0 & 0 & \\
\hline & Approve/disclose/limit SERPs & 24 & 35.6 & 5 & 7 & \\
\hline & Pay directors in stock & 23 & 11.8 & 0 & 0 & \\
\hline & Restrict non-employee director pensions & 14 & 31.1 & 0 & 1 & \\
\hline & Pension fund surplus reporting & 14 & 33.6 & 0 & 4 & \\
\hline & Require equity awards to be held & 12 & 27.5 & 0 & 0 & \\
\hline & No repricing underwater stock option & 11 & 31.6 & 3 & 4 & \\
\hline & Approve Executive compensation & 4 & 31.3 & 0 & 1 & \\
\hline & Hire independent compensation consultant & 4 & 39.9 & 1 & 2 & 1061 \\
\hline \multicolumn{7}{|c|}{ 111 - iाн } \\
\hline G_Delay & Repeal Classified Board & 549 & 57.5 & 116 & 219 & \\
\hline G_Other & Redeem or vote Poison Pill & 355 & 57.7 & 77 & 132 & \\
\hline G_Voting & Cumulative voting & 273 & 31.5 & 22 & 49 & \\
\hline G_Protection & Vote on future golden parachutes & 152 & 44.4 & 19 & 56 & \\
\hline G_Voting & Eliminate supermajority provision & 109 & 62.7 & 16 & 32 & \\
\hline $\mathrm{G}_{-}^{-}$Other & Remove antitakeover provisions \& Other & 42 & 41.4 & 2 & 8 & \\
\hline G_Voting & Confidential voting & 39 & 52.7 & 7 & 16 & \\
\hline G_Delay & Shareholders may call special meeting & 25 & 56.5 & 3 & 8 & \\
\hline G_Protection & Compensation Plans & 6 & 18.7 & 0 & 0 & \\
\hline G_Other & Adopt Antigreenmail & 3 & 30.7 & 0 & 1 & \\
\hline G_Protection & Maximum director liability & 3 & 15.5 & 0 & 0 & \\
\hline G_Voting & Require only majority vote & 2 & 50.1 & 0 & 2 & 1558 \\
\hline \multirow[t]{14}{*}{$\overline{\text { Other }}$} & Study Sell company & 162 & 15.8 & 2 & 7 & \\
\hline & Misc & 138 & 14.5 & 3 & 6 & \\
\hline & Double board nominees & 43 & 8.1 & 0 & 0 & \\
\hline & Change annual meeting location & 20 & 6.0 & 0 & 0 & \\
\hline & Reincorporate to U.S. state & 15 & 25.5 & 0 & 2 & \\
\hline & Change annual meeting date & 12 & 4.4 & 0 & 0 & \\
\hline & Affirm political nonpartisanship & 8 & 7.2 & 0 & 0 & \\
\hline & Vote on targeted share placement & 4 & 42.4 & 0 & 3 & \\
\hline & Issue post-meeting report & 3 & 5.5 & 0 & 0 & \\
\hline & Opt out of state takeover statute & 3 & 46.6 & 0 & 1 & \\
\hline & Disclose prior government service & 2 & 3.2 & 0 & 0 & \\
\hline & Improve post-meeting report & 2 & 6.6 & 0 & 0 & \\
\hline & Restore preemptive rights & 1 & 27.5 & 0 & 0 & \\
\hline & Nominee statement in proxy & 1 & 9.1 & 0 & 0 & 416 \\
\hline \multirow[t]{5}{*}{ Voting } & Majority vote to elect directors & 206 & 45.9 & 56 & 115 & \\
\hline & Majority vote shareholder committee & 128 & 15.9 & 8 & 9 & \\
\hline & No discretionary voting & 11 & 14.8 & 0 & 0 & \\
\hline & Counting shareholder votes & 6 & 15.4 & 0 & 0 & \\
\hline & Allow shareholder nominees i.e. Equal access to proxy & 5 & 22.0 & 1 & 2 & 356 \\
\hline
\end{tabular}




\section{Supplemental Appendix}

\section{Derivation of the Price reaction on the day of the vote}

In this Appendix we show how to calculate the average price expectation formed in the market prior to observing a given vote outcome $E(W \mid v)$. Note that an explicit calculation of this function is not necessary for our identification strategy; we only need it to be a continuous function around the vote threshold.

The market reaction on the day of the vote, given that we observe a vote $v$, is the difference between the market value of the firm after the vote and the average expected value before the vote $W(v)-E(W \mid v)$. If the market expected a vote $x$ but the realized vote was $v$ we can denote the market expectation on that day as $E(W \mid E(v)=x)$ and this event has a density probability function $f(v \mid E(v)=x)$. To calculate $E(W \mid v)$ we need to take into account that a given realized vote outcome $v$ may correspond to different prior expectations. Therefore $E(W \mid v)$ should take into account all the possible combinations of prior expectations that may have lead to $v$ :

$$
\begin{aligned}
E(W \mid v) & =\int_{x=0}^{x=100} E(W \mid E(v)=x) \frac{f(v \mid E(v)=x)}{\Phi(v)} g(x) d x \\
\Phi(v) & =\int_{x=0}^{x=100} f(v \mid E(v)=x) g(x)
\end{aligned}
$$

Where $g(v)$ is the density function of all the possible prior expectations on $v$, and $\Phi$ is a rescaling factor to ensure that we are computing an expectation.

Regardless of the specific distributions of the priors of the market $E(W \mid v)$ is the same in an arbitrarily close interval around the threshold of $50 \%$ of the votes $(E(W \mid v)$ is represented in Figure 1 by the dashed line).

To illustrate the shape of the market reaction to the outcome of the vote with reasonable distributions, we assume, that the value of the proposal $W(v)=0$ if $v<50 \%$ and $W(v)=1$ if $v \geqslant 50 \%$, and that the market reaction is given by $W(v)-E(W \mid v)$. In Figure SA1 we show $W(v)-E(W \mid v)$ for a particular example. We assume a population of firms with 100 shareholders each. Each shareholder vote is distributed iid, voting in favor of the proposal with probability $\rho$ and against with probability $(1-\rho)$. We also assume that each firm has a fixed $\rho$, but that it can be different across firms. We assume all $\rho$ are equally probable ex-ante so $\rho$ is uniformly distributed between 0 and 
100.

Figure 1 shows the expected market reaction for each vote outcome, taking into account how expections were formed prior to the vote. It reflects how votes that are far from the majority threshold carry virtually no market reaction, as the outcome of the vote is almost fully incorporated into prices before the meeting. The market reaction peaks at the majority threshold.

Figure SA1: Market Reaction to the Vote

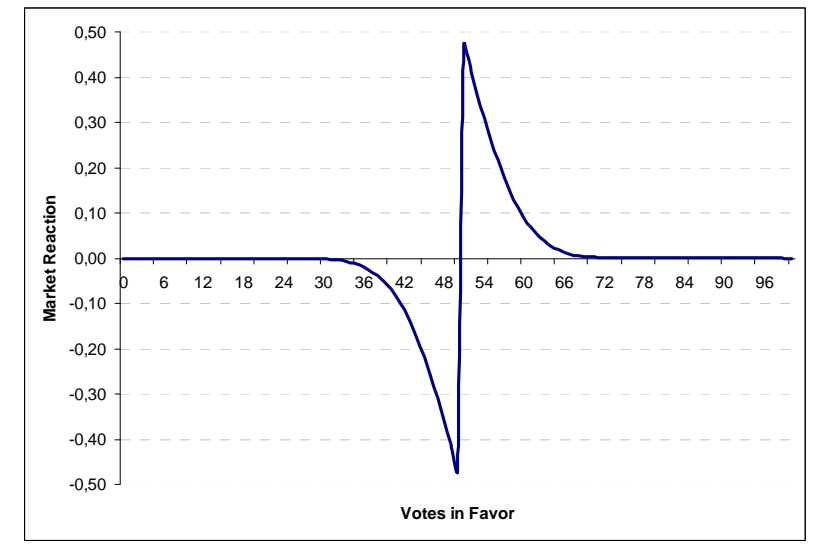

\section{Figures for Density Tests on the Vote Share (McCrary, 2008)}

Figure SA2: All Shareholder Govenance Proposals

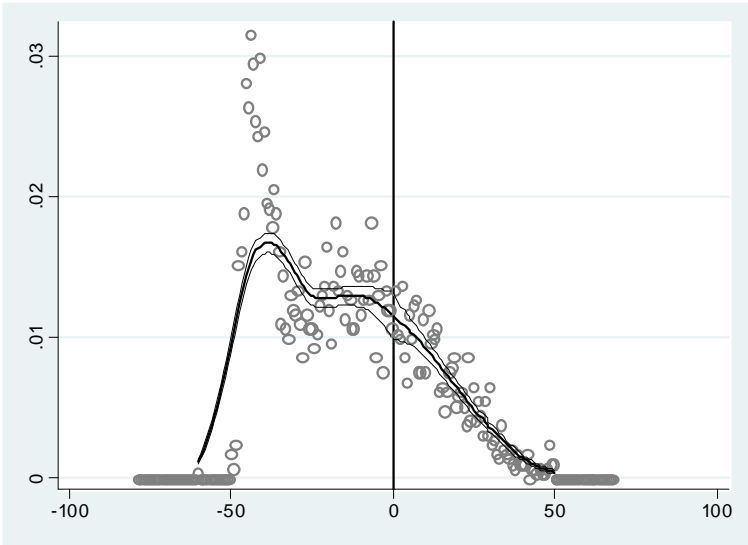


Figure SA3: Shareholder Governance Proposals to Remove Anti-Takeover Provisions (G-Index)

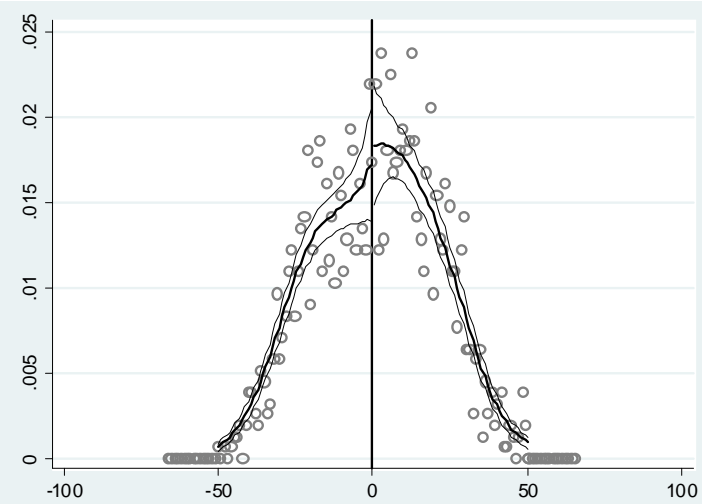

Figure SA4: Other Shareholder Proposals (nonG-index)

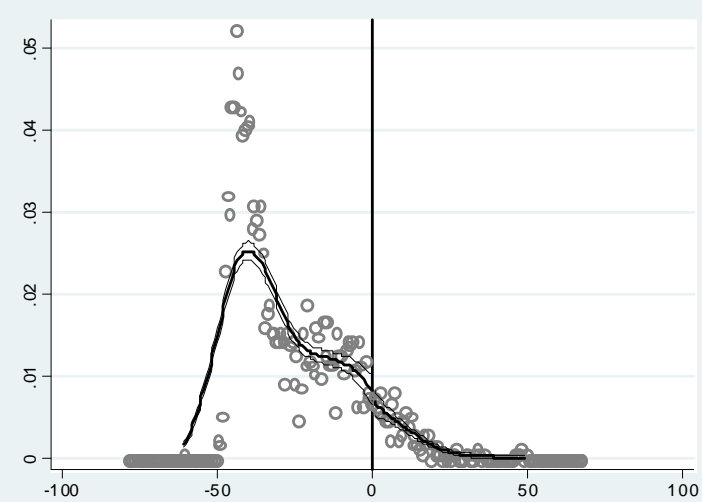




\section{Supplemental Appendix Table A}

\section{Abnormal Returns around the Threshold}

This table presents regressions of the abnormal returns on $\mathrm{t}=0$ on whether the proposal passed, allowing for polynomials of different order on the right hand side. Abnormal returns are computed using the Fama French and momentum factors from Carhart (1997). Columns 1-6 use two polynomials of increasing order in the vote share, v, one on each side of the threshold (right and left). Column 8 displays a unique polynomial of order 8 . The specification is equation 8. All columns control for year fixed effects, firm-meeting fixed effects and distance to the election effects; standard errors in parentheses are clustered by firm. Significance at the $10 \%, 5 \%$, and $1 \%$ levels are indicated by *,**, and *** respectively.

\begin{tabular}{|c|c|c|c|c|c|c|}
\hline Order of Polynomial: & $\begin{array}{c}\text { Order } 2 \\
(1)\end{array}$ & $\begin{array}{c}\text { Order } 3 \\
(3)\end{array}$ & $\begin{array}{c}\text { Order } 4 \\
(4) \\
\end{array}$ & $\begin{array}{c}\text { Order } 5 \\
(5)\end{array}$ & $\begin{array}{l}\text { Order } 6 \\
(6) \\
\end{array}$ & $\begin{array}{l}\text { One poly } \\
(7)\end{array}$ \\
\hline 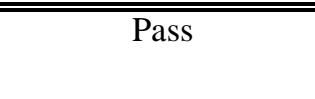 & $\begin{array}{l}0.00554^{* *} \\
(0.00268)\end{array}$ & $\begin{array}{l}0.00756^{* *} \\
(0.00359)\end{array}$ & $\begin{array}{l}0.0131^{* * *} \\
(0.00490)\end{array}$ & $\begin{array}{l}0.0125^{* *} \\
(0.00617)\end{array}$ & $\begin{array}{l}0.0141^{* *} \\
(0.00702)\end{array}$ & $\begin{array}{l}0.00828^{* *} \\
(0.00329)\end{array}$ \\
\hline right $\mathrm{V}$ & $\begin{array}{c}1.00 \mathrm{e}-05 \\
(0.000126)\end{array}$ & $\begin{array}{l}-0.000158 \\
(0.000286)\end{array}$ & $\begin{array}{l}-0.000704 \\
(0.000593)\end{array}$ & $\begin{array}{c}-0.000733 \\
(0.000940)\end{array}$ & $\begin{array}{l}-0.000425 \\
(0.00141)\end{array}$ & \\
\hline right $\mathrm{V}^{2}$ & $\begin{array}{r}-6.31 \mathrm{e}-08 \\
(2.37 \mathrm{e}-06)\end{array}$ & $\begin{array}{r}-8.49 \mathrm{e}-06 \\
(1.30 \mathrm{e}-05)\end{array}$ & $\begin{array}{r}-5.61 \mathrm{e}-05 \\
(4.57 \mathrm{e}-05)\end{array}$ & $\begin{array}{r}-5.99 \mathrm{e}-05 \\
(9.80 \mathrm{e}-05)\end{array}$ & $\begin{array}{c}-4.98 \mathrm{e}-06 \\
(0.000218)\end{array}$ & \\
\hline right $\mathrm{V}^{3}$ & & $\begin{array}{l}-1.14 \mathrm{e}-07 \\
(1.72 \mathrm{e}-07)\end{array}$ & $\begin{array}{l}-1.56 \mathrm{e}-06 \\
(1.30 \mathrm{e}-06)\end{array}$ & $\begin{array}{l}-1.75 \mathrm{e}-06 \\
(4.21 \mathrm{e}-06)\end{array}$ & $\begin{array}{l}2.17 \mathrm{e}-06 \\
(1.47 \mathrm{e}-05)\end{array}$ & \\
\hline right $\mathrm{V}^{4}$ & & & $\begin{array}{l}-1.43 e-08 \\
(1.23 e-08)\end{array}$ & $\begin{array}{r}-1.82 \mathrm{e}-08 \\
(7.92 \mathrm{e}-08)\end{array}$ & $\begin{array}{c}1.13 \mathrm{e}-07 \\
(4.78 \mathrm{e}-07)\end{array}$ & \\
\hline right $\mathrm{V}^{5}$ & & & & $\begin{array}{c}-0 \\
(5.44 \mathrm{e}-10)\end{array}$ & $\begin{array}{c}2.03 \mathrm{e}-09 \\
(7.34 \mathrm{e}-09)\end{array}$ & \\
\hline right $\mathrm{V}^{6}$ & & & & & $\begin{array}{c}0 \\
(0)\end{array}$ & \\
\hline left $\mathrm{V}$ & $\begin{array}{l}-0.000741^{* *} \\
(0.000322)\end{array}$ & $\begin{array}{c}-0.00113^{*} \\
(0.000653)\end{array}$ & $\begin{array}{c}-0.00315^{* * *} \\
(0.00115)\end{array}$ & $\begin{array}{c}-0.00264 \\
(0.00206)\end{array}$ & $\begin{array}{c}-0.00469 \\
(0.00333)\end{array}$ & \\
\hline left $V^{2}$ & $\begin{array}{l}1.74 \mathrm{e}-05^{* *} \\
(8.74 \mathrm{e}-06)\end{array}$ & $\begin{array}{c}4.06 \mathrm{e}-05 \\
(3.68 \mathrm{e}-05)\end{array}$ & $\begin{array}{l}0.000254^{* *} \\
(9.99 \mathrm{e}-05)\end{array}$ & $\begin{array}{c}0.000171 \\
(0.000269)\end{array}$ & $\begin{array}{c}0.000639 \\
(0.000601)\end{array}$ & \\
\hline left $V^{3}$ & & $\begin{array}{l}-3.50 \mathrm{e}-07 \\
(5.93 \mathrm{e}-07)\end{array}$ & $\begin{array}{c}-7.91 \mathrm{e}-06^{* *} \\
(3.31 \mathrm{e}-06)\end{array}$ & $\begin{array}{l}-2.94 \mathrm{e}-06 \\
(1.46 \mathrm{e}-05)\end{array}$ & $\begin{array}{l}-4.48 \mathrm{e}-05 \\
(4.78 \mathrm{e}-05)\end{array}$ & \\
\hline left $V^{4}$ & & & $\begin{array}{l}8.32 \mathrm{e}-08^{* *} \\
(3.72 \mathrm{e}-08)\end{array}$ & $\begin{array}{l}-4.01 \mathrm{e}-08 \\
(3.42 \mathrm{e}-07)\end{array}$ & $\begin{array}{c}1.69 \mathrm{e}-06 \\
(1.85 \mathrm{e}-06)\end{array}$ & \\
\hline left $V^{5}$ & & & & $\begin{array}{c}1.07 \mathrm{e}-09 \\
(2.87 \mathrm{e}-09)\end{array}$ & $\begin{array}{l}-3.22 \mathrm{e}-08 \\
(3.42 \mathrm{e}-08)\end{array}$ & \\
\hline left $V^{6}$ & & & & & $\begin{array}{r}2.39 \mathrm{e}-10 \\
(2.40 \mathrm{e}-10) \\
\end{array}$ & \\
\hline $\mathrm{V}$ & & & & & & $\begin{array}{c}-0.000621^{* * *} \\
(0.000234)\end{array}$ \\
\hline $\mathrm{V}^{2}$ & & & & & & $\begin{array}{l}-1.21 \mathrm{e}-05^{*} \\
(6.71 \mathrm{e}-06)\end{array}$ \\
\hline $\mathrm{V}^{3}$ & & & & & & $\begin{array}{l}1.32 \mathrm{e}-06^{* *} \\
(5.16 \mathrm{e}-07)\end{array}$ \\
\hline $\mathrm{V}^{4}$ & & & & & & $\begin{array}{c}2.40 \mathrm{e}-08^{*} \\
(1.26 \mathrm{e}-08)\end{array}$ \\
\hline $\mathrm{V}^{5}$ & & & & & & $\begin{array}{c}-1.07 \mathrm{e}-09^{* *} \\
(4.19 \mathrm{e}-10)\end{array}$ \\
\hline $\mathrm{V}^{6}$ & & & & & & $\begin{array}{c}-0 * * \\
(0)\end{array}$ \\
\hline $\mathrm{V}^{7}$ & & & & & & $\begin{array}{c}0^{* * *} \\
(0)\end{array}$ \\
\hline $\mathrm{V}^{8}$ & & & & & & $\begin{array}{l}0^{* *} \\
(0) \\
\end{array}$ \\
\hline Observations & 3904 & 3904 & 3904 & 3904 & 3904 & 3904 \\
\hline R-squared & 0.012 & 0.012 & 0.014 & 0.015 & 0.015 & 0.013 \\
\hline
\end{tabular}




\section{Supplemental Appendix Table B}

\section{Pre-differences in Meeting Characteristics as a Function of the Vote Outcome}

This table tests whether passing a vote on the meeting date is systematically related to meeting characteristics. Each row corresponds to a different dependent variable and each entry comes from a separate regression. Each entry in the table reports the coefficient on whether a proposal passed. Columns 1 and 2 report the estimated effect of passing a vote on outcome variable levels. Column 1 presents estimates without controlling for a polynomial in the vote share and, therefore, estimates the average effect of passing relative to not passing. Column 2 includes the polynomial in the vote share of order 4 on each side of the threshold such that it estimates the effect at the discontinuity. All columns control for year fixed effects and standard errors (in parenthesis) are clustered at the firm level. Significance at the $10 \%, 5 \%$, and $1 \%$ levels are indicated by *, **, and $* * *$ respectively.

(1)

(2)

\begin{tabular}{lcc}
\hline \hline A. & & \\
Number of Proposals on the day of & $-0.645^{* * *}$ & -0.055 \\
Meeting & $(0.122)$ & -0.294 \\
\cline { 2 - 3 } B. & & \\
Number of Withdrawn Proposals & $-0.424^{* * *}$ & 0.098 \\
& $(0.130)$ & $(0.223)$ \\
\cline { 2 - 3 } C. & -0.018 & -0.023 \\
Proponent is Activist Fund & $(0.019)$ & $(0.058)$ \\
\cline { 2 - 3 } & & \\
Proponent is Company & 0.012 & 0.016 \\
& $(0.009)$ & $(0.028)$ \\
\cline { 2 - 3 } & & -0.019 \\
Proponent is Individual & $0.013^{*}$ & $(0.026)$ \\
\cline { 2 - 3 } & $(0.007)$ & \\
Proponent is Public Pension Fund & -0.002 & 0.001 \\
& $(0.012)$ & $(0.038)$ \\
\hline \hline & & \\
Polynomial in the vote share & 0.002 & $(0.019)$ \\
\hline
\end{tabular}

